\title{
Eesti etnofarmakognoosia elujõust kummelite näitel
}

\begin{abstract}
Ain Raal, Elmar Arak
Teesid: Uute ravimtaimede avastamisel ja ammu tuntud droogide kasutusalade laiendamisel on etnofarmakognoosia farmaatsiateaduse igati tunnustatud ja nüüdisaegne suund. Käesolevas artiklis analüüsitakse eesti etnofarmakognoosia elujõulisust kummelite kui populaarseimate ravimtaimede näitel. Rahvameditsiinilise andmestiku läbitöötamine on võimaldanud siinkirjutajatel püstitada hüpoteesid, mille kohaselt võiks lõhnava kummeli ja teekummeli toimeid pidada samaväärseteks ning kasutada lõhnava kummeli ürti teekummeli õisikute asendajana. Kirjutises refereeritud farmakognostiliste, fütokeemiliste ja farmakoloogiliste uuringute andmed on esivanemate kogemusi igati kinnitanud. See annab alust ja julgust lähtuda edasiste farmatseutiliste uuringute planeerimisel etnofarmakognoosiast ka teiste ravimtaimede puhul.
\end{abstract}

Märksõnad: eesti etnofarmakognoosia, farmaatsia, kummel, rahvameditsiin, ravimtaimed

Farmaatsiateaduse, kitsamalt farmakognoosia ja fütokeemia ülesanneteks on muu hulgas uute ravimtaimede ja toimeainete ning droogide uudsete kasutusviiside leidmine. Esmapilgul tundub ehk uskumatuna, et tänapäeva teadusele omase põhjalikkusega on suudetud läbi uurida vaid 5-6\% taimeliikide keemiline koostis. Seetõttu on uurimisobjektide valikul ja tööhüpoteeside püstitamisel oluline arvestada rahvameditsiiniga, kus ravimtaimi on kasutatud sadu aastaid (Samuelsson 1992: 13). See on niisiis farmaatsiateaduse igati tunnustatud ja nüüdisaegne suund. Mainekas farmakognost Gunnar Samuelsson märgib samas, et kuigi niisugust lähenemisviisi nimetatakse tavapäraselt etnofarmakoloogiaks, väljendab selle sisu hoopis täpsemalt teine termin - etnofarmakognoosia.

Eesti rahvameditsiini andmestikku klassifitseeriv uuring on näidanud, et kõrvuti loomsete, keemiliste, maagiliste ja muude ravivahenditega kasutasid meie esivanemad kõige laialdasemalt just ravimtaimi. Sõltuvalt haigustest või organsüsteemidest varieerus nende osa vahemikus $40-92 \%$ kõikidest

http://haldjas.folklore.eeltagused/nr34/kummel.pdf 
ravivahenditest. Eriti laialdaselt langes valik ravimtaimede kasuks nt nakkushaiguste (92\%), günekoloogiliste vaevuste (85\%), sooleparasiitide (83\%) ja seedehäirete $(80 \%)$ korral. Kõrvuti alkaloidide ja flavonoidide allikatega läksid haiguste leevendamisel kõige sagedamini käiku eeterlikku õli sisaldavad ravimtaimed (Raal \& Sõukand 2005).

\section{Kummel kui Eesti populaarseim ravimtaim}

Eesti apteekrite seas tehtud küsitlused ja varasemad kirjandusallikad näitasid, et läbi aegade on apteekides ravimtaimedest enim küsitud eeterliku õli allikana tuntud kummelit. Näiteks 1933. aastal vajasid Eesti rohulaod ühtekokku $3100 \mathrm{~kg}$ teekummeliõisikuid. 1997. aastal oli selle droogi nõudlus küsitluses osalenud apteekides kokku $1034 \mathrm{~kg}$. Seejuures olid igas kolmandas apteegis kummeliõisikud vähemalt korra aastas defitsiidiks. Võrdluseks: köömneid vajati samal ajal $499 \mathrm{~kg}$, linaseemneid $475 \mathrm{~kg}$, kibuvitsavilju $313 \mathrm{~kg}$ ning leesikalehti $300 \mathrm{~kg}$ (Raal \& Arak \& Rekand \& Bender 1998). Mainitud uurimus ei hõlmanud kogu Eestit ja seega ei väljenda toodud arvud droogivajadusi tervikuna.

1974. ja 1984. aastal küsitleti kõiki vabamüügiapteekide juhatajaid, kes pakkusid välja enda poolt juhitava apteegi kummeliõisikute aastavajaduse. Tehti kindlaks reaalselt apteegis müüdud teekummeli ja lõhnava kummeli õisikute kogused. Selgus, et kummeliõisikute aastavajadus oli Eestis nimetatud aastatel vastavalt $16393 \mathrm{~kg}$ ja $19837 \mathrm{~kg}$. 1984. aastal plaanimajanduse tingimustes täideti kummeliõisikute varumise plaan $77 \%$-liselt. Kuid plaan oli tegelike vajadustega võrreldes pehmelt öeldes vildakas. Reaalselt varuti tollel aastal $1550 \mathrm{~kg}$ teekummeli ja $155 \mathrm{~kg}$ lõhnava kummeli õisikuid. Arvutus näitab, et esimeste arvelt kaeti aastavajadusest ainult 7,8\% ja lõhnava kummeli õisikuid varuti ligi kümme korda vähem ( $0,8 \%$ üldvajadusest) (Arak \& Raal \& Vahar et al. 1986). Jääb veel lisada, et 1974. aastal oli kõikide droogide koguvajadus Eestis 99,4 tonni ja vajadus kummeliõisikute järele moodustas sellest umbes kuuendiku (Raal \& Arak \& Rekand \& Bener 1998).

Seega oli 20. sajandil Eestis enimkasutatavaks ravimtaimeks kummel, millele piltlikult öeldes järgnes tükk tühja maad ja alles seejärel teised droogid. Veelgi enam - teekummel oli üheks populaarseimaks ravimtaimeks kogu N Liidus (Muravjova 1981: 248). Venemaal arvati looduslikult levinud teekummeli õisikute aastavajaduseks 150-250 tonni, kuid 1990. aastatel kasvas tarbimine järsult kuni 3000 tonnini (Jakovlev \& Blinova 1996: 167). Saksamaal hinnati 1990. aastatel teekummeli õisikute aastavajadust ligi 4000 tonnile, farmaatsiatööstus tootis neist 90 fütopreparaati (Bisset \& Wichtl 1994: 324). 


\section{Teekummel ja lõhnav kummel nõukogude farmaatsias}

Rahvapärases keelepruugis kummelina tuntud taim on meie flooras esindatud kahe vastavasse perekonda kuuluva liigiga. Valgete keelõitega teekummel (Chamomilla recutita (L.) Rauschert, syn. Matricaria recutita L., syn. M. chamomilla L.; vt foto 1) kasvab Eestis metsistunud kultuurtaimena vaid hajusalt, sagedamini lääneosas ning droogi saadakse peamiselt taime kultiveerimise teel. Seevastu ilma keelõiteta lõhnav kummel (Chamomilla suaveolens (Pursh) Rydb., syn. M. suaveolens (Pursh) Buchen, syn. M. discoidea DC., syn. M. matricarioides (Less.) Porter p.p.; vt foto 2) kasvab sagedase taimeliigina õuedel, jalgteedel, tihedaks tallatud kohtades jm (Eesti taimede määraja 1999: 278; Tammeorg \& Kook \& Vilbaste 1984: 56-60).

Pool sajandit Eestis kehtinud N Liidu farmakopöa lubas lõhnava kummeli õisikuid kasutada teekummeli õisikute (Flores Chamomillae) asendajana, kuid ainult välispidiseks otstarbeks (NLF 1968: 291-292). Farmakopöa viimane väljaanne lõhnava kummeli õisikuid enam isegi ei maini (NLF 1990: 239-241). Lõhnav kummel sobis üksnes teekummeli õisikute asendajana välispidiseks otstarbeks ka üleliiduliste õpikute autorina tuntuks saanud esifarmakognost Darja Murajvova arvates (Muravjova 1981: 244-248). Eestis praegu kehtiv Euroopa farmakopöa sisaldab peatüki teekummeli õisikute kohta (Matricariae flos), kuid lõhnavat kummelit see autoriteetne allikas ravimtaimena ei tunnusta (European Pharmacopoeia 2005: 2965-2966).

N Liidu viimane farmakopöa mainib muu hulgas kummeliõisikute toimet põletikuvastane ja spasmolüütiline (NLF 1990: 241). Teekummel leidis varasemal ajal n-ö ametlikku kasutamist ka gaaside vastu maos ja sooles, higileajava vahendina, uriini- ja sapierituse soodustamiseks jm. Välispidiselt soovitas ametlik meditsiin kummeliteed kuristamiseks, kompressideks paisetele ja raskelt paranevatele haavadele ning silmalaugude põletikele, samuti inhalatsiooniks kurgu limaskesta põletike korral jm. Neid toimeid osati juba 1980. aastatel siduda teekummelis leiduvate bioloogiliselt aktiivsete ainetega (Tammeorg \& Kook \& Vilbaste 1984: 59).

Lõhnavale kummelile andis tollane farmakognoosiadotsent Johannes Tammeorg järgmise hinnangu: Lõhnava kummeli õisikud ei sisalda hamasuleeni. Samuti on erinev flavoonglükosiidiline koostis. Siiski sarnaneb lõhnav kummel terapeutiliselt toimelt teekummeliga (Tammeorg \& Kook \& Vilbaste 1984: 60). Samas mainib autor, et rahvameditsiinis tarvitati selle taime teed köha ja külmetuse korral higileajava vahendina ning kompressideks samade haiguste puhul nagu teekummelitki.

Võrdluseks on huvitav mainida, et eelmainitud D. Muravjova seisukoht lõhnava kummeli õisikutest kui üksnes välispidisest vahendist ei ole muutu- 
nud ka tema ja kaasautorite 2002. aastal ilmunud raamatus (Muravjova \& Samõlina \& Jakovlev 2002: 256-260). Seevastu D. Muravjova kõrval tuntumate nõukogude farmakognostide hulka kuuluvate Gennadi Jakovlevi ja Klavdia Blinova 1996. aastal trükivalgust näinud raamatus sisaldub juba ka lõhnava kummeli (Flores Chamomillae discoideae) õisikuid käsitlev peatükk, mille andmetel toimib droog põletikuvastaselt ning leiab vesitõmmisena välispidist kasutamist kurgu kuristamiseks, vannide ja klistiirina (Jakovlev \& Blinova 1996: 171-173). Selles teoses on lõhnavat kummelit peetud küll eraldi käsitlust väärivaks droogi allikaks, kuid siingi ei jõuta kaugemale tema välispidisest kasutamisest. Samaks on jäänud autorite käsitlus ka nende 2004 . aastal ilmunud raamatus (Jakovlev \& Blinova 2004: 171-172). Ometi oli selleks ajaks maailmas, aga eriti just $\mathrm{N}$ Liidus ilmunud rida uurimusi (vt edaspidi), mis tõestavad lõhnava kummeli hoopis mitmekülgsemaid kasutusvõimalusi. See näitab selgelt, et isegi teadusuuringute tulemused jõuavad oma ala tunnustatud spetsialistide koostatud erialaraamatutesse alles mitmekümneaastase hilinemisega, kui üldse jõuavad. Veelgi suurem on mõistetavalt teaduskirjanduse lõtk rahvameditsiiniga.

Lõhnava kummeli teatava alavääristamise üks põhjusi võis olla tõsiasi, et erinevalt teekummelist ei sisalda tema eeterlik õli hamasuleeni. Viimasel on aga eelkõige põletikuvastane ja antiallergiline toime (Tammeorg \& Kook \& Vilbaste 1984: 60; Turova \& Sapopnikova \& Ven Dõok Li 1987: 222-226; Muravjova \& Samõlina \& Jakovlev 2002: 256-260; Barnes \& Anderson \& Phillipson 2002: 125-129; Weiss \& Fintelmann 2000: 107). Nii eelmainitu, aga ka suhteliselt vähesed ja pinnapealsed teadusuuringud võisidki olla põhjuseks, miks suhtuti lõhnava kummeli kasutamisega seonduvasse üpris ettevaatlikult. Mainimata ei saa jätta sedagi, et kummelite farmakognostilise uurimise alal on $\mathrm{N}$ Liidus kaitstud vähemalt kolm farmaatsiakandidaadi väitekirja (Arak 1981; Prossovski 1986; Raal 1989).

\section{Teekummel ja lõhnav kummel tänapäevases farmaatsias}

Lõhnavat kummelit ei käsitleta erinevalt teekummelist ravimtaimena Euroopa ega ka kogu maailma tänapäevased tunnustatud taimekäsiraamatud (nt Barnes \& Anderson \& Phillipson 2002; Blumenthal 2000; WHO monographs on selected medicinal plants 1999; Weiss \& Fintelmann 2000; Bisset \& Wichtl 1994 jt). Samas levib see Põhja-Ameerikast pärinev taim Euroopas praegu metsistunud kultuurtaimena üsna laialdaselt (Barnes \& Anderson \& Phillip- 
son 2002: 125-129). Mõnes allikas (nt Bunney 1993: 104) mainitakse üsna otsekoheselt, et lõhnavat kummelit kasutatakse praegu harva. Muidu toimivat ta teekummeliga sarnaselt, kuid põletikuvastane toime tal puuduvat.

Mõlema kummeli toimet on eksperimentaalselt uuritud juba 1920. aastatel ja jõutud järeldusele, et märkimisväärne erinevus kahe droogi efektiivsuses puudub (Santesson 1925: 829-831). Kuid 1930. aastate lõpul uuriti küülikutel ja merisigadel mõlema kummeli eeterliku õli mõningaid toimeid ning autorid jõudsid seisukohale, et spasmolüütilise, meteorismivastase ${ }^{1}$ ja sooleparasiitidevastase toime poolest ei suuda lõhnava kummeli eeterlik õli asendada teekummelist destilleeritut (Jaretzky \& Neuwald 1939: 50$53)$.

Saksa professorid, Euroopas tunnustatud fütoterapeudid Rudolf Fritz Weiss ja Volker Fintelmann kirjutavad lõhnava kummeli kohta nii:

Teise maailmasõja ajal lootsid paljud inimesed, et seda väga laialt levinud ja seega kergesti kättesaadavat taime saab kasutada teekummeli adekvaatse asendajana, kuid see ei olnud nii (Weiss \& Fintelmann 2000: 44).

Autorid ütlevad sõnaselgelt välja, et lõhnav kummel ei asenda teekummelit ning tema spasmolüütiline ja meteorismivastane toime ei küüni teekummelile ligilähedalegi. Küll aga on mainitute hinnangul lõhnaval kummelil siiski ka üks kasulik omadus: selle õisikud toimivad ussiajatina. Niisuguse mõju avastas kuulus Prantsuse fütoterapeut Henri Leclerc naaskelsabatõve põdevate sõdurite ravil. Pandagu tähele, et siin on "õnnistus" antud juba ka kõnealuse taime seespidiseks kasutamiseks. Pealegi tõdetakse, et võrreldes analoogilise toimega hariliku soolikarohuga (Tanacetum vulgare L.) on lõhnav kummel hästi talutav (Weiss \& Fintelmann 2000: 107).

Ungarist pärit autorid mainivad, et kuigi lõhnav kummel jõudis nende maale 19. sajandi lõpul ja hakkas massiliselt levima alles 20. sajandi alguses, kasutatakse teda mitmel pool rahva seas kui teekummeli asendajat (Máthé \& Tyihák 1960: 48).

Seega on asjalood kahe kummeli võimaliku asendamise problemaatikas vägagi vastukäivad. Mis aga teekummeli enda toimet puudutab, siis avaldab teekummel praegusel ajal väga maineka Saksa Komisjon E materjalide (Commission E Monographs) andmetel põletikuvastast, spasmolüütilist, haavade paranemist soodustavat, desodoreerivat, antibakteriaalset, bakteriostaatilist, naha ainevahetust stimuleerivat jm toimet. Seespidiselt kasutatakse seda põhiliselt gastrointestinaaltrakti spasmide ja põletike (maos ja sooltes) korral (Blumenthal 2000: 59). 
Rõhutamist vajab veel üks väga oluline asjaolu: eranditult kõik viidatud allikad käsitlevad teekummeli ja lõhnava kummeli õisikute kasutamist, kuid ükski neist ei maini lehtede, ürdi või teiste taimeosade (droogide) kasutamist.

Kummeli mõlemad liigid on olnud Eestis tuntud ja kasutusel juba mitu sajandit. Hea kohanemisvõimega lõhnav kummel on levima hakanud alles 19. sajandi teisel poolel, teekummel seevastu on sisse toodud juba enne 17. sajandit (Vilbaste 1993: 422-423). Samas on kummelite esmakordne mainimine Eestis siiski üsnagi vaieldav.

Järgnevalt vaatlemegi, mida on kummelite kasutamise kohta öelda Eesti etnomeditsiinil ning kuidas see seostub meil ja mujal teostatud farmakognostiliste ja farmakoloogiliste uuringutega.

\section{Millest kõnelevad kummeli rahvapärased nimetused}

Kummelite rahvapäraste nimetuste selgitamisel tugineti peamiselt Eesti Kirjandusmuuseumi Eesti Rahvaluule Arhiivi, aga ka Tartu Ülikooli farmaatsia instituudi rahvameditsiini kartoteegi ja muudele andmetele (Vilbaste 1993: 422-423; Wallner 1929: 5-170).

Kirjandusmuuseumi fondides leiduvad ülestähendused pärinevad kõikjalt üle Eesti, viidates kummelitele kui laialdaselt tuntud ravimtaimedele. Nende nimetustest moodustavad suure osa modifikatsioonid, mis arvatavasti tulenevad saksakeelsest nimetusest kamille: kammel (15\% kõikidest nimetustest), kumel (14\%), kamel (13\%), kaamel (6\%) jt (Raal 1987: 24). Gustav Vilbaste arvates on sedasorti sünonüümid uuemaaegsemad, olles levima hakanud seoses ebasündsate nimetuste taandumisega. Nimelt viitab rida rahvapäraseid nimetusi kana teatavale kehaosale, mis mõistagi otsekoheselt ka välja öeldakse (kannapersed, kanapersseätses, saksa kanaperselill, saksa kanaperserohi jt) (Vilbaste 1993: 422).

Kindlat vahet saab kahel kummeliliigil nimetustele tuginedes teha suhteliselt harva. Sellele viitavad muu hulgas välistunnustele toetuvad rahvapärased taimenimed (teekummel = valge kummel jt ning kollased kummelid jt = lõhnav kummel). Eesliide saksa- on omane vaid teekummelile (Raal 1987: 24). Harva annab liigist aimu kasvukohale viitav nimetus (teekummel = põldkummel, põllukummel, põldätses jt, samas aga murukummel, õuekummel, kodukummel jt = lõhnav kummel) (Raal 1982: 8). Enamasti on mitmesugused nimetuse ubinhein modifikatsioonid ja laiemalt ounaga seostamine omased küll lõhnavale kummelile (Raal 1987: 24), kuid G. Vilbaste järgi omistati selliseid nimetusi siiski vahel ka teekummelile: ubinahein, uppinhain, ubinhein jt (Vilbaste 1993: 422). Lõhnav kummel hakkas Saksamaal levima 
Berliini botaanikaaiast 19. sajandi keskel (Weiss \& Fintelmann 2000: 44). Samas on lõhnava kummeli üks laialt levinud rahvapärane nimi (ubinahein) mainimist leidnud juba August Wilhelm Hupeli 1818. aastal ilmunud raamatus, kuigi taime ennast leiti Eestis esimest korda alles 1857. aastal Tartu ümbrusest (Vilbaste 1993: 420-422). Niisiis ei ole rahvapärimustes kummeliliigi identifitseerimine kaugeltki alati üheselt võimalik. Sellel võib olla nii levikuline kui ka toimega seostuv põhjus. Võimalik, et üks kummelitest ei olnud igal pool levinud ja seega ka tuntud. Tõenäoline on seegi, et teekummeli ja lõhnava kummeli toimeid peeti sarnasteks.

Paljud rahvapärased taimenimetused viitavad nende kasutamisele tervise parandamisel (kopsurohi, silmarohi, kurgurohi jt) (Vilbaste 1993: 80). Sellest annavad aimu nii taimenimetustes sisalduvad organid, organsüsteemid ja haigused (jooksjarohi, luuvaluhain, solknarohi jt) kui järelliide -rohi (LõunaEestis valdavalt -hain) (Vilbaste 1993; Tammeorg \& Kook \& Vilbaste 1984). Sellel foonil on huvitav mainida, et kummelite puhul sedasorti nimetused puuduvad. See võib muidugi tuleneda nende toimete ja kasutusvõimaluste mitmekesisusest (vt kummelite etnofarmakoloogiast). Erandiks on suhteliselt rohked nime ubinhain modifikatsioonid - sageli nimetati ravimtaimi heinaks (Vilbaste 1993: 60). Kindlalt viitavad kummelite kasutamisele ravimtaimena või vähemalt sellest tee keetmisele niisugused nimetused nagu tervisekummelid, theelill, theehein, kummeltee, kammeltee jt (Vilbaste 1993: 421-422; Raal 1982: 9). Eks anna sellest aimu teekummeli praegu kehtiv botaaniline nimigi.

Üsna silmatorkavalt on kummeli rahvapärastes nimetustes esindatud koduloomad - hobukumel, saksakana, seakumel, lehmakummeltee, koerakommel, kassikummel jt (Vilbaste 1993: 420-422; Raal 1982: 9). Raske öelda, kas siin võiks näha seost kummeli kasutusvõimalustega rahvaveterinaarias või on selliste nimede omistamisel olnud sootuks teistsugused põhjused. Ilmselt ei saa kajastuvaid loomaliike kummelite puhul siduda nende välise sarnasusega. Kahtlane, kas toimetele viitavad sellisedki nimetused nagu kanapaskur või koerakusekommelid.

Nimetuse seos loomaga võis vahel olla (nime)maagilinegi:

Koera kiskumist suitsetati koerakarvadega ja pandi katki muljutud koerakommelid peale (ERA II 201, 101 (41) < Karja khk - Kaljo Lepp (1938)).

Eelnevast lähtudes tuleb tõdeda, et kummelite rahvapärased nimetused viitavad eelkõige nende taimeliikide päritolule, välimusele ja kasvukohale. Farmakognostilises ja farmakoloogilises mõttes on taimenimedes talletatu 
hoopiski vähem kõnekas. Küll aga võimaldas etnomeditsiiniline andmestik luua esimese tööhüpoteesi: lõhnava kummeli ja teekummeli bioloogiliselt aktiivsete ainete kompleks on keemiliselt ja farmakoloogiliselt lähedased ning lõhnav kummel toimib teekummeliga praktiliselt samaväärselt ja on kasutatav selle asendajana.

\section{Kummelite etnofarmakognoosiast}

Kummelite kogumise ja kuivatamise kohta on teada üsna vähe. Neid koguti õitsemise ajal, harilikult juunis enne jaanipäeva (EKnS c, $56(4)<$ Viljandi linn; ERA II 292, 259/65 (7) < Kose). Kuivatamiseks sobilike paikadena mainitakse vilu, nõrgalt tuuletõmbelist kohta (rehe all, aida peal, lakas jt), kuhu droog laotati õhukese kihina (Raal 1982: 15).

Kodusel teel valmistatud ravimvormidest olid kasutusel peamiselt vesitõmmised - tüüpilisemalt tee, kompresside või vannide kujul. Üksikasjalikke tehnoloogilisi õpetusi nende valmistamiseks on säilinud kahjuks vähe ja nendeski on tuntav tagasiside teaduslikust kirjandusest: mainitakse näiteks "eeterliste mõjuainete" lenduvust droogi keetmisel. Pikemaaegset keetmist üldiselt välditi ja droog jäeti veega "tõmbama" kinnisesse anumasse (Raal 1982: $15 ; 1987: 25$ ).

Kui kurk oli haige, keedeti kummeliteed joomiseks. Ka pärnaõietee oli hea. Tee keetmine käis nii, et kui vesi keema hakkas, lasti kummelite või pärnaõitega minuti osa vast keeda ja siis lasti "tõmmata". Joodi kuumalt, pehmendas kurku ja põletik vähenes. Kui kaasnes palavik, kadus ka see teega. Teele lisati ka mett sisse. Paljud andsid kurguhaigele kuuma piima meega (RKM II 373, 11/2 (12) < Põltsamaa khk, Põltsamaa l - Helle Kull (1984)).

Hoopis harvemini valmistati kummelitest tinktuuri, siirupit, salvi, õli jm. Kummelist pressiti ka mahla ja droogi tarvitati auru tegemiseks. Maagia piirimaile ulatub komme kummeleid saunaviha sisse siduda, mis pidavat aitama "haigusi välja vihelda". Üsna tähelepanuväärseks ravimvormiks võib pidada kummelipulbrit:

Tõmmata ninna (kui nohu) upinhaina õite pulbrit (ERA II 193, 618 (3) < Adavere v - J. Lääts (1938)). 
Koduste kummeliravimite valmistamisel kombineeriti neid teiste ravimtaimede (lina, mänd, kadakas, üheksavägine, raudrohi, pärn, humal jt), toiduainete (leib, piim, koor, suhkur, või, rasv, mesi jt) või keemiliste ainete ja apteegist soetatuga (piiritus, viin, naatriumsulfaat, oliiviõli, jood, petrooleum, tärpentin jt) (Raal 1982: 15-19).

Huvitav on jälgida, millist taimeosa meie esivanemad kasutasid. Enamasti on selleks "õied" (botaaniliselt: õisikud) ja paljudel juhtudel on taimeosa täpsustamata. Võimalik, et seda pole respondendilt küsitudki. Võib aga oletada, et kui mainitakse vaid taime kui sellist ja organ jäetakse täpsustamata, siis vähemalt teatud puhkudel peetakse silmas ürti. Seda spekulatsiooni näib toetavat tõsiasi, et umbes kümnendik küsitlejatest viitavad kummeli(te) ladva, lehtede, varte või kogu maapealse osa kasutamisele (Raal 1987: 24).

Mõned näited:

Kodukummel - seda peale panna, värskelt, kui palavik oo, käte-jalge sees või mujal. Ladvadest tehakse teed (ERA II 195, 234 (100) < Varbla khk - Richard Viidalepp (1936)).

Kaela ümber asetati kuumutatud kummelivartega täidetud sukasäör (RKM II 111, 563 (21) - Aleksei Rand (1961)).

Kummel-sahvt õite kui ka varre seest välja pitsitada hää rohi paisetele, kes valu vähendab ja ennemalt määndab (EKnS c, 56 (4) < Ostrovi kog $<$ Viljandi l? (1891)).

Obinahein. Taime tarvitatakse kõhutõbe vastu, kui kõht lahti on ja valutab. Oied ja lehed kuivatatakse ja siis pruugitakse otse tee vee viisi (EKnS c, 56 (2) < Ostrovi kog < Tarvastu khk? (1891)).

Nikastand kohale seotakse lõhmusekoort ümer ja soojas hoida. Kummelitega võib kah kinni mässida. Kummelid on ühed kanged rohud, nemad kisuvad kangesti (ERA II 256, 473 (30) < Kolga-Jaani khk - Johannes Raidla (1939)).

Eelnev võimaldas püstitada teise tööhüpoteesi: lõhnava kummeli ja teekummeli bioloogiliselt aktiivsete ainete kompleks on kvalitatiivselt sarnane nii õites, lehtedes kui ka vartes ning õisikute asemel on võimalik kasutada ürti. 


\section{Kummelite etnofarmakoloogiast}

Ühtekokku leiti andmed 98 väga erineva haigusliku ilmingu või terviseprobleemi leevendamise kohta kummelitega: ülemiste hingamisteede haigestumise ja külmetamisega seotud hädad (angiin, (kurgu)haigus, kurguvalu, häälekähin, köha, (krooniline) nohu, otsaesisekoopa põletik, kõrvapõletik ja kõrvavalu, igemepõletik, aga ka närvipõletik, samuti üldine ja kehaosade külmetus, palavik, kusjuures palavikuravis kasutatakse kummelit nt higistama ajamiseks); paised, sh hambapaised, ja paistetused, sh põsepaistetus ja putukapistetest tekkinud paistetus, samuti kõikvõimalikud muud nahahädad (kroonilised nahahaigused, (pea)kärnad, kõõm, lööve, seenhaigus, aga ka põletikuline nahapunetus ehk roos); (pea)haavad ja raskesti paranevad haavad ning nikastused, aga ka muud liigesehädad, nagu liigese- ja luuvalud, podagra ning podagraga kaasnevad "puhutised"; krambid, sh lihase- ja kõri- ning lastel esinevad krambid, samuti emakakrambid, naistehaigused, sh menstruatsioonivaevused (liigverega menstruatsioon, viibiv menstruatsioon, emakaverejooks, valgevoolus, nn naistevalud), ka sünnitamise järelvalud ning rindade kinnisus (kummelit on kasutatud imetavate emade piimaerituse suurendamiseks) ning raseduse katkemise oht; kõhuhädad (nii kõhukinnisus kui ka kõhulahtisus, lihtsalt kõhuvalud ja kõhuhaigus, laste kõhurikked ning hemorroidide korral tekkivad "puhutused"); nakkushaigused (difteeria, leetrid ja kollatõbi); rinnahaigus ehk tuberkuloos; silmahaigused (silmavalu, silmade punetamine, rähmasus ja pisaravool); südamehaigus, südamepööritus, lendva ja kasvaja (viimast küll täpsustamata). Kummel on olnud heaks abimeheks ja kosutusvahendiks kõhnuse ja verevaesuse korral või pärast raskeid haigusi, üldise ja jalgade nõrkuse puhul, aidanud peavalu ja kõrvades kohisemise, samuti unetuse korral. Seda on kasutatud ka nn kosmeetiliste hädade leevenduseks, nagu jalgade higistamine, kõva, kortsunud või rasvane näonahk, (lisatud on rasvasus, selgitusega: omastamata jäänud toidurasvad), aga ka lihtsalt näonaha pehmendamiseks ja nahale mati tooni andmiseks. Juuksehoolduses on kummelit kasutatud rasvaste juuste puhul, aga ka blondide juuste värvuse säilitamiseks ja juustele kuldse läike andmiseks. Veterinaarias on kummelit kasutatud samalaadsete hädade korral: loomade kõhukinnisuse korral, sh soolestiku lahtistamiseks ning veiste kõhuvalu ja seedehäirete korral; loomade kusekinnisuse ja lehma verekusemise raviks; lehmadel udarapaistetuse alandamiseks ja piimaerituse suurendamiseks, samuti paaritamiseelselt ja poegimisjärgselt, hobustel aga silmahädade rähmasuse ja nn silmahaiguse (nahk käib silmanurgast silmamunale) raviks (täpset loendit vt Raal 1982: 36-39). 
Kokkupuude kummeliga algas inimesel juba pärast sündimist:

Sündinud imikutele oli kõige esimeseks söögiks lahja kummelitee. Ka hiljem, kui lapsel juhtus kõht korrast ära minema, jäeti toidukord vahele ja anti kummeliteed (RKM II 355, 447 (110) < Põltsamaa khk Helle Kull (1981)).

Omal kombel oli kummel vahel justkui universaalseks ravimtaimekski:

Minu emal oli kummel alati käepärast. Silmale kompressiks ja külmetuse vastu ja kõhurohuks ja. Teisi rohtusid ei olnud (RKM II 331, 391 (39) < Väike-Maarja khk - Mall Hiiemäe (1978)).

Enim püüti kummeleid tarvitada silmahaiguste (18\% kõikidest kummelitega seotud teadetest), köha (10\%), seedehäirete (8\%), paisete (8\%), kõrvahaiguste (7\%), hambahaiguste (5\%) jt vaevuste leevendamiseks. Tuleb rõhutada, et pooled (49\%) kummelite rahvapärastest kasutusviisidest eeldasid kodus valmistatud "ravimite" seespidist kasutamist (Raal 1987: 25). Lisaks tõsistele terviseriketele loodeti kummelitelt kasu ka ilu teenistuses, rahvapäraseks kosmeetikavahendiks on ju kummel jäänud tänapäevani. Kõrvuti inimeste tohterdamisega oli kummelitel oluline koht ka rahvaveterinaarias, kusjuures kasutusalad kattusid mitmeti humaanmeditsiini valdkondadega.

Püüdkem kummeli kasutusviisid teisendada toimeteks (tabel 1). Etnofarmakoloogia tunneb ilmselgelt kummeleid eelkõige kui põletikuvastaseid ja spasmolüütilisi ravimtaimi, mis vastab ka nüüdisaegsele seisukohale nende põhitoimetest (Tammeorg \& Kook \& Vilbaste 1984: 58-59; NLF 1990: 241; Barnes \& Anderson \& Phillipson 2002: 125; Blumenthal 2000: 59 jt).

Lisaks sellele kattuvad rahvameditsiini ja teadusliku meditsiini andmetel mitmed teisedki toimed (haavade paranemist soodustav, higieritust suurendav, seedetegevust korrastav jt). Mitmed tänapäeva teadmistele vastavad toimed, nagu antibakteriaalne ja bakteriostaatiline, võiksid üsna tihedalt seostuda rahvameditsiiniski tuntud põletikuvastase toimega. Naha ainevahetust stimuleeriv mõju võiks aga, vähemalt osaliseltki olla seotud kummelite kui rahvapäraste kosmeetikumide kasutamisega. Reumavastast toimet seevastu võib seostada ühelt poolt põletikuvastase ja teiselt poolt diureetilise (uriinieritust soodustava) mõjuga.

Ülaltoodud kummelite kasutusalade loetelust ja tabelis 1 avaldatud toimetest selgub, et kummeleid kasutati mitte ainult välispidiselt, vaid laialdaselt ka seespidiselt.

See võimaldab püstitada kolmanda hüpoteesi: lõhnavat kummelit võib kasutada ka seespidiseks otstarbeks. 
Ain Raal, Elmar Arak

Tabel 1. Kummelite toimed rahvameditsiinis ja teaduslikus meditsiinis

\begin{tabular}{|c|c|}
\hline Rahvameditsiin & Teaduslik meditsiin \\
\hline Põletikuvastane & Põletikuvastane \\
\hline Spasmolüütiline & Spasmolüütiline \\
\hline Haavade paranemist soodustav & Haavade paranemist soodustav \\
\hline Seedetegevust korrastav & Seedetegevust korrastav \\
\hline Higieritust suurendav & Higieritust suurendav \\
\hline Kasvajavastane & - \\
\hline Kollatõvevastane & - \\
\hline Üldtugevdav & - \\
\hline Diureetiline & Diureetiline \\
\hline Kootav & - \\
\hline Kõhukinnisuse vastane & - \\
\hline Kõhulahtisuse vastane & - \\
\hline Menstruatsiooni soodustav & - \\
\hline Piimanõristust soodustav & - \\
\hline Tuberkuloosivastane & - \\
\hline Antireumaatiline & - \\
\hline Valuvaigistav & - \\
\hline Kosmeetiline* & Naha ainevahetust soodustav** \\
\hline- & Kõhupuhitusvastane \\
\hline- & Sooleparasiitide vastane \\
\hline- & Desodoreeriv \\
\hline- & Antibakteriaalne \\
\hline- & Bakteriostaatiline \\
\hline
\end{tabular}

* Raal 1982: 36--39.

** Tammeorg \& Kook \& Vilbaste 1984: 58--59; NLF 1990: 241; Barnes \& Anderson \& Phillipson 2002: 125; Blumenthal 2000: 59; Jaretzky \& Neuwald 1939: 50--53; Weiss \& Fintelmann 2000: 44 jt.

\section{Teekummeli eeterliku õli komponendid: bioloogiline aktiivsus}

Teekummeli eeterliku õli üheks iseloomulikuks terpenoidiks ja põhitoimeaineks on hamasuleen. Viimase toimeid on uuritud juba enne Teist maailmasõda ja sellele järgnevatel aastakümnetel ning talle omistatakse põletikuvastast (Albath 1939; Pommer 1942; Arnold \& Jung \& Reuber \& Spielmann 1949; Schmidt 1954; Bogs \& Meinhard 1955 jt), antiartriitilist, kantserostaatilist (Kraul \& Schmidt 1955; Kraul \& Schmidt 1957) ja antiastmaatilist 
(Tuszek 1953) toimet. Mõned uurijad on hamasuleeni põletikuvastases toimes kahelnud, sest sinepiõli ja ultraviolettkiirtega indutseeritud eksperimentaalsete põletike korral ei osutunud see ühend efektiivseks (Brock \& Kottmeier \& Lorenz \& Veigel 1954; Oettel \& Wilhelm-Kollmannsperger 1955, 1956). Hamasuleeni põletikuvastane toime leidis aga kinnitust uuemas uuringus tänu dekstraanödeemi meetodi kasutamisele (Verzárné-Petri \& Szegi \& Marczal 1979). Põletikuvastane toime on ka prohamasuleenil (Jung \& Wendler 1953). Hamasuleeni põletikuvastast ja antiallergilist omadust on selgitatud adrenokortikotroopse hormooni (AKTH) mobiliseerimisega ja neerupealise funktsiooni tugevdamise kaudu (Stern \& Milin 1956, 1957). Nagu näitasid mikrobioloogilised uuringud, ei toimi asuleen ja petrooleetriga valmistatud teekummeli ekstrakt Candida albicansile, gram-negatiivsetele ja gram-positiivsetele mikroobidele, kuid proasuleeni mõjul minetab streptolüsiin toime mõne minuti jooksul (Kienholz 1963). In vitro muudab hamasuleen pepsiini toimetuks (Thiemer \& Stadler \& Isaac 1972), vähendab merisea soole kontraktsioone, mis tekitati atsetüülkoliini, histamiini, serotoniini ja bradükiniiniga ning pidurdab adrenergilise $\beta$-blokaatoriga mõjustatud hiirtel astmahoogusid, mis tekitati histamiini, serotoniini või bradükiniiniga (Jeličić-Hadžović \& Stern 1972).

Teekummeli eeterliku õli põletikuvastane toime tuleneb ka bisaboloolist ja selle oksiididest. Bisabolool omab gvaiasuleeniga võrreldavat põletikuvastast toimet (Janku \& Zita 1954), olles seejuures vähem toksiline kui gvaiasuleen, hamasuleen (Jakovlev \& Schlichtegroll 1969) ja sünteetilised põletikuvastase toimega ained (Isaac 1975). (-)-Bisabolool on ligikaudu kaks korda tugevama põletikuvastase toimega kui (+)-bisabolool ja sellest tulenevalt on sünteetilise ratsemaatilise bisabolooli põletikuvastane toime kaks korda nõrgem kui (-)-bisaboloolil (Isaac 1975, 1979; Jakovlev 1975), bisabolooloksiididel A ja B ning bisaboloonoksiidil (Jakovlev \& Isaac \& Thiemer \& Kunde 1979). Bisabolool takistab indometatsiini, stressi või piiritusega esile kutsutava haavandi tekkimist, kiirendades keemiliselt või termiliselt tekitatud haavandi paranemist (Szelenyi \& Isaac \& Thiemer 1979). Bisabolooli raviefekt avaldub mittetoksilistes annustes II ja III astme põletuste korral (Zita 1955). Bisabolooloksiidid on spasmolüütilise ja põletikuvastase toimega (Verzárné-Petri \& Szegi \& Marczal 1979).

Farneseenil on granulatsiooni ${ }^{2}$ ja epitelisatsiooni soodustav toime, seega aitab ta kaasa kudede taastumisele. Spasmolüütiline (Gava \& Janku 1957) ja põletikuvastane toime farneseenil puudub (Verzárné-Petri \& Szegi \& Marczal 1979).

En-in-bitsükloeetri spasmolüütiline toime on soole eksperimentaalse atsetüülkoliini, histamiini, serotoniini ja bradükiniiniga tekitatud kokkutõmbe 

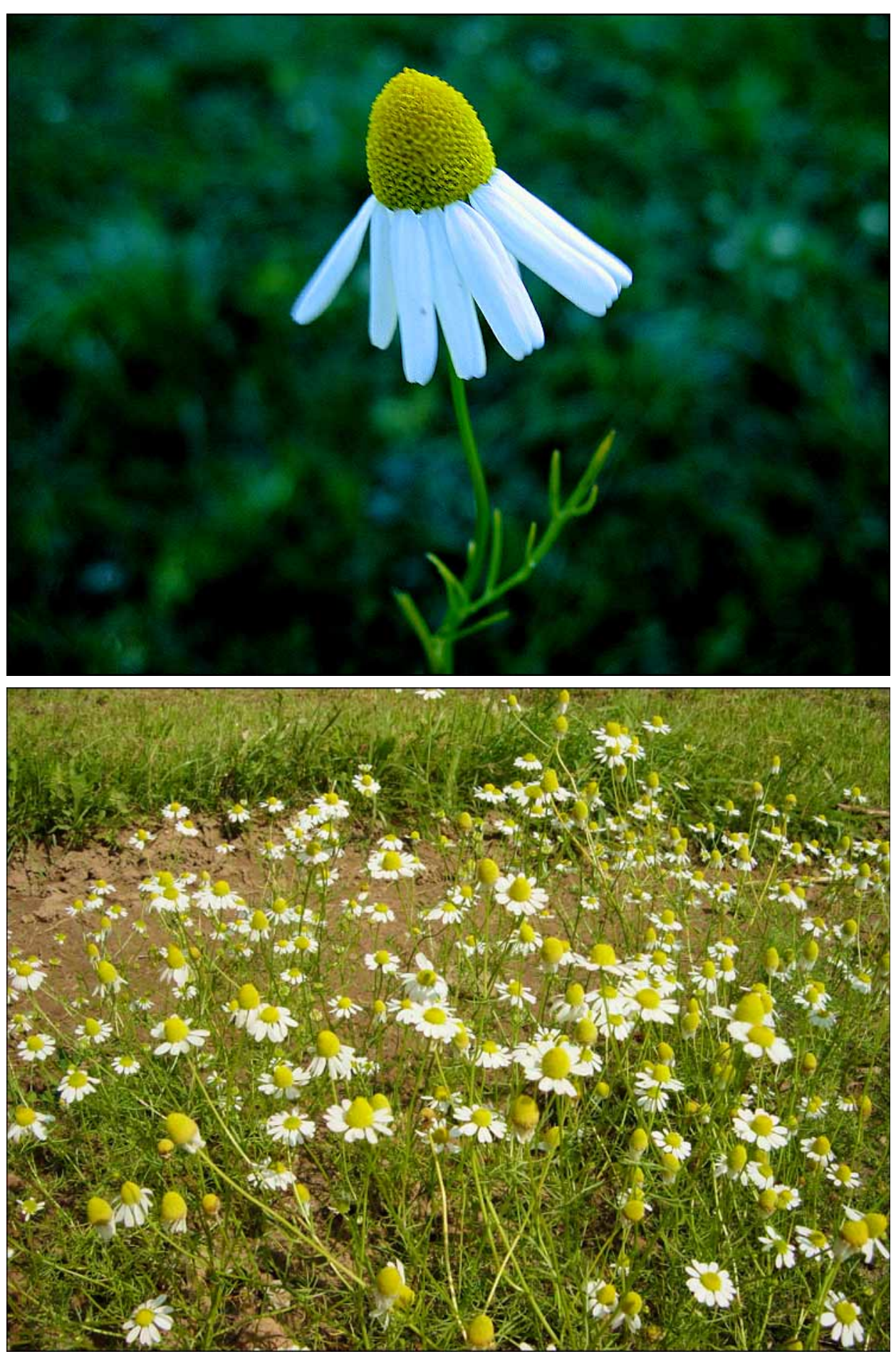

Fotod 1 ja 2. Teekummel on Eestis kultiveeritav ravimtaim. Ain Raali fotod. 
korral ligikaudu 50 korda tugevam kui papaveriini toime. Keelealuselt manustatuna tekitab ta hiire jalal turse ja põletikulise reaktsiooni, kuid ei takista hiire jalale serotoniini, histamiini või bradükiniiniga tekitatud turse arengut, ei toimi merisea anafülaktilise šoki ${ }^{3}$ korral ega oma bakteriostaatilist toimet gram-negatiivsetele ja gram-positiivsetele mikroobidele (Breinlich 1966; Breinlich \& Scharnagel 1968). Ei avalda põletikuvastast toimet (Verzárné-Petri \& Szegi \& Marczal 1979).

Farnesool toimib sääskede juveniilhormoonile, aidates seega kaasa nende paljunemisele (Schmialek 1961).

Teekummeli eeterlik õli ergutab kesknärvisüsteemi, tugevdades selle reflektoorset tegevust ja stimuleerides ühtlasi pikliku aju tegevust (Turova 1974: 423). Eeterlik õli avaldab selektiivset inhibeerivat toimet gram-positiivsetele mikroobidele ja fungitsiidset ${ }^{4}$ toimet Candida albicansile (Aggag \& Yousef 1972). Eeterlik õli tervikuna ei oma fungitsiidset toimet, kuid tema komponentidel (hamasuleen, bisabolool, en-in-bitsükloeetrid) on erinev fungitsiidne efektiivsus (Szalontai \& Verzárné-Petri \& Florian 1976).

\section{Teekummeli eeterliku õli solubilisaat: ${ }^{5}$ väljatöötamine}

Kuigi teekummeli õisikud olid toonases N Liidus kasutusel ametliku droogina (NLF 1968; NLF 1990; GOSR 1977), puudusid sellest tööstuslikult valmistatavad ravimid. Kasutati vaid teekummeli õisikute vesitõmmiseid, mida valmistati apteekides ja koduselt. Teistes riikides toodeti kummeli baasil tööstuslikult mitmesuguseid ravimeid ja osa neist olid saadaval ka Eesti apteekides.

Saksa päritolu Kamillosan on standardiseeritud alkohoolne ekstrakt, mis sisaldab $150 \mathrm{mg} \%$ eeterlikku õli, mitte vähem kui $3 \mathrm{mg} \%$ hamasuleeni ja $50 \mathrm{mg} \%$ bisabolooli. Tema lahjendusi kasutati inhaleerimiseks, suu ja kurgu loputamiseks, pesemiseks ja vannideks. Vastunäidustused ja kõrvaltoimed preparaadil puuduvad (Nasemann \& Menzel 1975: 49-54).

Rumeenia päriolu Romasulan sisaldab $96 \mathrm{ml}$ teekummeli ekstrakti, $0,3 \mathrm{ml}$ 6\%-lise hamasuleenisisaldusega eeterlikku õli ja emulgaatorina 4,0 g Tween 80 (polüsorbaat 80 ). Tarvitatakse antiseptilise ja desodoreeriva vahendina nii sees- kui ka välispidiselt. Kõrva-nina-kurguhaiguste praksises kasutatakse loputusteks (Kljujev \& Babajan 1979).

Inhalat-Kamille (Saksamaa) on teekummeli õisikute alkohoolne põletikuvastase ja spasmolüütilise toimega ekstrakt, mille peamisteks toimeaineteks on eeterlik õli ja selle komponendid hamasuleen ja bisabolool. Kasu- 
tatakse lahjendatult (1-2\%-line lahus mineraalvees) ainult inhalatsiooniteraapias.

Kamilla csepp (Ungari) sisaldab teekummeli ekstrakti ja eeterliku õli alkohoolset lahust. Kasutatakse tee valmistamiseks, suu loputuseks, vannideks ja juuste hooldusvahendina.

Inhaleeritavad ravimid ei tohi sisaldada ärritava toimega aineid ja ballastaineid, mille toimet on vähe uuritud. Ülalmärgitud ekstraheerimise teel valmistatud ravimid sisaldavad lisaks eeterlikule õlile flavonoidseid ühendeid ja koliini ning mitmesuguse koostisega ekstraktiivaineid. Teekummeli flavonoididel puudub põletikuvastane toime (Verzárné-Petri \& Szegi \& Marczal 1979) ja nende spasmolüütiline toime pole ülemiste hingamisteede põletike ravi seisukohalt oluline. Teekummeli vesitõmmises lahustub vähe eeterlikku õli, mis sisaldab põletikuvastase, spasmolüütilise, fungitsiidse ja antiallergilise toimega kompenente. Teekummeli eeterlik õli ei sobi inhaleerimiseks oma füsikokeemiliste omaduste tõttu ka puhtal kujul. See ei lahustu vees, kuid pindaktiivsete ainete (nt tviinid) abil on võimalik valmistada püsivad teekummeli eeterliku õli solubilisaadid vees (Ellö 1962).

Solubilisaadi valmistamiseks kasutatav eeterlik õli eraldati teekummeli õisikutest destilleerimisel veeaurudega ning õli koguti florentiini vastuvõtjas dietüüleetri kihti. Pärast saadud lahuse veetustamist veeta naatriumsulfaadiga eraldati dietüüleeter vaakumdestillatsiooniga. Selliselt saadud teekummeli eeterlik õli solubiliseeriti Tween 80 abil destilleeritud vees. $\mathrm{N}$ Liidus oli ravimite valmistamiseks lubatud kasutada vaid Tween 80 (GOSR 1977), mis pole mürgine ega oma ärritavat resorbtiivset toimet (Abramzon \& Gajevoi 1979). Teekummeli eeterliku õli solubiliseerimisel Tween 80 abil vahekorras 1:8 saadi sinaka värvusega iseloomuliku lõhnaga selged nõrga mõru maitsega vedelikud. Edasisteks uuringuteks valmistati $0,1 \%$-, $0,2 \%$ - ja $0,8 \%$ lise eeterliku õli sisaldusega solubilisaadid.

\section{Teekummeli eeterliku õli solubilisaat: võimalik toksilisus}

Teekummeli eeterliku õli toksilisus on madal. Peroraalsel manustamisel määratud $\mathrm{DL}_{50}$ (dosis letalis - surmav annus $=\mathrm{LD}_{50}$ ) on võrdne $5 \mathrm{~g} / \mathrm{kg}$ roti kehakaalu kohta (Habersang \& Leuschner \& Isaac \& Thiemer 1979). 0,1\%-, 0,2\%- ja 0,8\%-lise teekummeli eeterlikku õli sisaldusega solubilisaatide ja Tween 80 lokaalse toime ja limaskestalt mahapesemise selgitamiseks teostati katsed konna söögitoru ripsepiteelil. Katseteks valiti sügisel kogutud konnad kaaluga 35-40 g. Mõõdeti korgitükikese liikumise kiirus katseloomade rips- 
epiteeli kontrollkatsetes Ringeri lahuse ja solubilisaatide ning Tween 80 vesilahustega, mida manustati aerosoolina. Kontrollkatsete tulemusel langes korgitükikese liikumise kiirus ehk ripsepiteeli aktiivsus ajas eksponentsiaalselt 57 minuti jooksul $50 \%$.

Katsed solubilisaatide ja Tween 80 lahustega teostati kahes variandis. Esimese variandi korral toimiti ripsepiteelile esmalt solubilisaadi ja seejärel Tween 80 lahusega, teise variandi korral esmalt Tween 80 lahusega ja seejärel solubilisaadiga. Solubilisaadi ja Tween 80 lahuste manustamisele eelnes kolm ripsepiteeli 1-minutilist loputamist Ringeri lahusega. Arvestades ajafaktorit arvutati välja ripsepiteeli aktiivsus, aktiivsuse muutust aga väljendati protsentides kontrollkatsete suhtes.

Katsetulemustest selgus, et ühekordne 0,1\%-lise solubilisaadi ja 0,8\%lise Tween 80 lahuse manustamine aerosoolina ripsepiteeli aktiivsust peaaegu ei mõjusta. Ripsepiteeli aktiivsuse vähenemist täheldati solubilisaadi ja Tween-80 korduval manustamisel lühikeste intervallide järel. Analoogsed tulemused saadi ka 0,2\%-lise solubilisaadi ja 1,8\%-lise Tween 80 lahusega. 0,8\%-lise solubilisaadi manustamise järel vähenes ripsepiteeli aktiivsus märgatavalt (kuni 46,9\%) ja korduva manustamise järgselt kahanes see veelgi. Aktiivsus ei taastunud ka Ringeri lahusega pesemise järgselt. Analoogsed tulemused saadi ka katsete teise variandi korral. 2\%-lise solubilisaadi $1 \mathrm{ml}$ intraperitonaalne manustamine 20-22 g kaaluvatele hiirtele ei kutsunud esile mürgistusnähte, mis viitab preparaadi heale talutavusele.

Kirjeldatud uuringute tulemuste alusel järeldati, et $0,1 \%$ - ja $0,2 \%$-lise teekummeli eeterliku õli sisaldusega solubilisaadid, mis on valmistatud Tween 80 abil vahekorras 1:8, ei ole aerosoolina manustamisel limaskestadele mürgised (Arak 1980, 1981).

Foto 3. Illustratsioon raamatust Köhler's Medizinal-Pflanzen (Verlag von Fr. Eugen Köhler (Saksamaa) 1887).

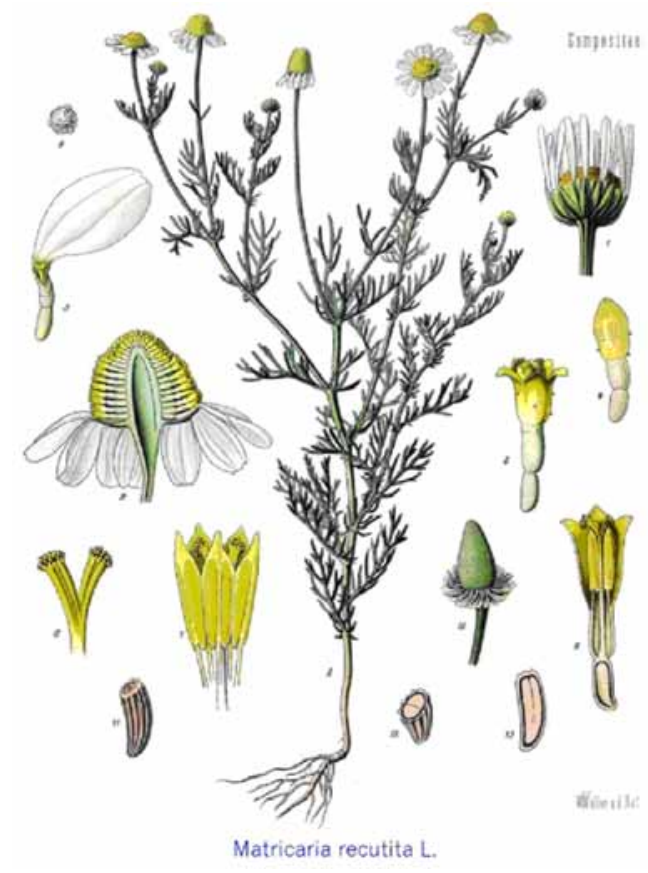




\section{Teekummeli eeterliku õli solubilisaat: kliinilised uuringud}

Teekummeli eeterliku õli $0,1 \%$-lise solubilisaadi kliinilised uuringud viidi läbi Tartu Ülikooli otorinolaringoloogia kateedri kliinilises baasis. Solubilisaati manustati ülemiste hingamisteede haiguste (mittespetsiifilised põletikud, kroonilised ja akuutsed farüngiidid, rinofarüngiidid, larüngiidid) raviks. Aerosoolteraapia läbis 451 patsienti. Ravikuur koosnes 6-12 seansist kestvusega 5 minutit, mille käigus pihustati $3 \mathrm{ml}$ solubilisaati. Akuutsete põletike korral tervistus $66 \%$ patsientidest, paranemine saavutati $29 \%$-1 ja ravi ei andnud tulemusi 5\% patsientidel. Krooniliste põletike korral olid ravi tulemused vastavalt järgmised: $18 \%, 76 \%$ ja $6 \%$. Seisundi paranemine saabus 24 päeva pärast, akuutsed põletikunähud kadusid 5.-6. päevaks. Krooniliste põletike korral lõpetati ravi 9-12 seansi järel seisundi ilmse paranemise tõttu. Ravi käigus uuriti ka 133 patsiendi ninaneelu mikrofloorat. Enne uuringute algust isoleeriti ninaneelust 170 mikroobitüve. Prevaleerusid mittehemolüütilised ja viridans-streptokokid, patogeensed kuldsed kobarkokid, epidermise stafülokokid ja sartsiinid. Aerosoolteraapia tulemusel mikroobide hulk oluliselt ei muutunud, kuid vähenes patogeensete ja epidermise stafülokokkide hulk. Täheldati viridans-streptokokkide ja hemolüütiliste streptokokkide tüvede hulga suurenemist.

Negatiivselt laetud aerosoolosakeste teraapia teekummeli eeterliku õli solubilisaadiga läbis 203 krooniliste ülemiste hingamisteede mittespetsiifilise põletikuga patsienti. Ravikuur koosnes 5 minuti pikkusest 6-14 seansist, mille käigus pihustati $3 \mathrm{ml}$ solubilisaati. Ravi tulemusel tervenes $53 \%$ patsientidest, seisundi paranemine saavutati $47 \%$-l haigetest. Seisundi paranemine ilmnes 2-4 päeva järel ja enamikul juhtudest võis ravi lõpetada 9-12 seansi järel. Uuriti 64 patsiendi ninaneelu mikrofloorat ja nende tundlikkust erütromütsiini, penitsilliini, neomütsiini, levomütsetiini, monomütsiini, streptomütsiini ja tetratsükliini suhtes. Mikroflooras prevaleerusid patogeensed kuldsed kobarkokid, viridans-streptokokid, mittehemolüütilised ja hemolüütilised streptokokid. Negatiivselt laetud aerosoolosakeste teraapia tulemusel vähenes patogeensete kuldsete kobarkokkide ja hemolüütiliste streptokokkide hulk ning täheldati kuldsete kobarkokkide tüvede hulga suurenemist. Aerosoolosakeste teraapia tulemusel võis täheldada antibiootikumide suhtes resistentsete tüvede vähenemise tendentsi.

Järeldati, et teekummeli eeterliku $0,1 \%$-list solubilisaati võib aerosoolosakeste teraapias kasutada kartmata mikrofloora tundlikuse vähenemist antibiootikumide suhtes (Arak \& Jents \& Siirde 1973: 149-150; Arak \& Jents 
\& Tammeorg 1974: 271-272; Jents \& Arak 1977a: 15; 1977b: 27-28; 1978). Seega leidis tõestust teekummeli eeterliku õli põletikuvastane toime.

\section{Lõhnava kummeli seespidine kasutamine: võimalik toksilisus}

Lõhnava kummeli seespidise kasutamise üheks eelduseks on võimaliku toksilisuse puudumise tõestamine. Mürgisuse väljendajaks on $\mathrm{DL}_{50}$. Tavaliselt väljendatakse seda kas milligrammides või grammides arvutatuna katselooma kehakaalu $1 \mathrm{~kg}$ kohta. Teekummeli eeterlikul õlil on, nagu mainitud, $\mathrm{DL}_{50} c a 5 \mathrm{~g} / \mathrm{kg}$. Selle määramise ajal oli lõhnava kummeli $\mathrm{DL}_{50}$ veel määramata. See tehti kindlaks Tartu Ülikooli farmaatsia kateedri ning Eksperimentaalse ja Kliinilise Meditsiini Instituudi koostööna 1987. aastal. Katses kasutati 54 valget rotti (Wistar, kehakaal 140-170 g). Katseloomad jagati üheksasse gruppi ja neile manustati suukaudselt 1-10 g lõhnava kummeli eeterlikku õli $1 \mathrm{~kg}$ kehakaalu kohta. Selgus, et uuritav eeterlik õli toimib annusest sõltumata suhteliselt aeglaselt. Katseloomade suremus ilmnes alles kolmandal päeval pärast manustamist, kusjuures koguste $1 \mathrm{~g} / \mathrm{kg}, 2,5 \mathrm{~g} / \mathrm{kg}$ ja $3 \mathrm{~g} / \mathrm{kg}$ manustamisel suri vastavalt $0,15 \%, 67 \%$ ja $86 \%$ katseloomadest. Annuse $5 \mathrm{~g} / \mathrm{kg}$ korral moodustas katsealuste letaalsus $100 \%$. Olenevalt tulemuste arvutamise meetodist saadi lõhnava kummeli eeterliku õli $\mathrm{DL}_{50}$ lõppresultaadiks $3,33 \mathrm{~g} / \mathrm{kg}$ või $3,32 \mathrm{~g} / \mathrm{kg}$.

Seega võib väita, et lõhnava kummeli eeterliku õli mürgisus on võrreldes teekummeli õliga küll pisut kõrgem, kuid siiski sellega samas suurusjärgus. See asjaolu võiks olla üheks oluliseks lähtekohaks lõhnava kummeli seespidisel kasutamisel (Raal \& Rooma 1988).

\section{Lõhnava kummeli kasutamine teekummeli asendajana: solubilisaadi, vesitõmmiste ja pulbrite mikrobioloogiline uuring}

Mõlema kummeli eeterliku õli antimikroobse toime uurimiseks valmistati neist eeterliku õli solubilisaadid veega, vesitõmmised ja pulbrid. Esimesed saadi, solubiliseerides $1 \mathrm{~g}$ eeterlikku õli $8 \mathrm{~g}$ Tween-80 kui pindaktiivse aine abil destilleeritud veega mahuni $100 \mathrm{ml}$. Vesitõmmised valmistati vastavalt N Liidu 10. farmakopöa (NLF 1968: 370-372) leotiste ja keediste tegemise 
juhendile. Täiendavalt valmistati pikendatud ekstraktsiooniajaga ( 1 tund) keedis. Pulbri saamiseks peenestati droog ja sõeluti läbi sõela, mille avade diameeter oli $0,2 \mathrm{~mm}$. Preparaadid steriliseeriti ja segati kindlates vahekordades lihapeptoonpuljongiga, uurides nende toimet sellistesse söötmetele lisatud patogeensetesse haigusetekitajatesse nagu Staphylococcus aureus ja Escherichia coli.

Selgus, et lõhnava kummeli solubilisaat pärsib testmikroobide elutegevust kontsentratsioonis $1 \%$, kuid teekummeli vastav preparaat avaldab neile mõju juba kontsentratsioonis $0,5 \%$. Vesitõmmiste toime eelmainitud mikroobidesse on võrreldes solubilisaadiga suhteliselt nõrk. Kuid vastav mikrobioloogiline aktiivsus on lõhnava kummeli õisikutel pisut suurem kui teekummeli õisikutel ja lõhnava kummeli ürt inhibeerib testmikroobide elutegevust pisut tugevamalt kui sama taimeliigi õisikutest valmistatud vesitõmmised. Erineva valmistusviisiga vesitõmmistest osutus kõige efektiivsemaks pikendatud ekstraktsiooniajaga keedis. Kummelipulbrid takistasid üksnes E. coli elutegevust, kuid ei avaldanud antimikroobset toimet $S$. aureus suhtes. Toime erinevused kahe kummeliliigi ning õisikutest ja ürdist valmistatud pulbrite vahel puudusid.

Tööst järeldati, et lõhnava kummeli ürt ei jää toimelt alla õisikutele ning mõlemad taimeosad on kasutatavad preparaatide valmistamiseks, mille antimikroobne toime on uuritud mikroobide suhtes praktiliselt samaväärne teekummeli vastavate preparaatidega (Raal 1989a).

\section{Lõhnava kummeli kasutamine teekummeli asendajana: vesitõmmiste täiendav mikrobioloogiline uuring}

Tartu Ülikooli farmaatsia ja mikrobioloogia instituutide koostöös uuriti teeja lõhnava kummeli vesitõmmiste antimikroobset aktiivsust ning toimet Escherichia coli ja Helicobacter pylori pinnastruktuuride aktiivsusele (Annuk 1998). Mõlema kummeli õisikutest valmistati erinevatel menetlustel mitmesugused vesitõmmised (leotised, külmad matseraadid ${ }^{6}$ ja külmad steriliseeritud matseraadid, vesitõmmised eelnevalt alkoholiga ekstraheeritud droogist). Leotiste antimikroobset toimet uuriti difusioonimeetodil agaris. Vastavate katsete tulemusel pidurdustsoonid puudusid, mis näitas, et teeja lõhnava kummeli õisikutest valmistatud leotistel puudub antimikroobne toime $E$. coli ja $H$. pylori tüvede suhtes.

Tee- ja lõhnava kummeli vesitõmmiste toimet märgitud mikroobide pinnastruktuuridele uuriti soolaagregatsioonitesti (Ljungh \& Brown \& Wadström 
1985) abil. Katsete tulemusel selgus, et tee- ja lõhnava kummeli leotised blokeerisid enamiku E. coli tüvede agregeerumisvõimet ja seejuures oli aktiivsem lõhnava kummeli leotis. Järeldati, et tee- ja lõhnava kummeli leotistel on $E$. coli tüvede agregatsiooni ${ }^{7}$ takistav toime ja mõlema kummeli õisikutes esinevad sarnased sisaldusained, mis vähendavad $E$. coli tüvede hüdrofoobseid omadusi. Mõlema kummeli vesitõmmised kahandasid ka $H$. pylori mikroobitüvede hüdrofoobseid omadusi, kusjuures lõhnava kummeli vesitõmmiste agregatsiooni blokeeriv toime oli tugevam kui teekummelil. Vähendades mikroobiraku hüdrofoobsust, väheneb ka tema võime kinnituda peremeesorganismi rakuretseptorite külge. Sellega on võimalik seletada tee- ja lõhnava kummeli vesitõmmiste efektiivsust infitseeritud haavade ravis (Türi \& Türi \& Annuk \& Arak 1999; Annuk 2002: 54-61).

Nende tulemuste alusel võib väita, et lõhnava kummeli vastav toime ei jää teekummelile alla, vaid koguni ületab seda.

\section{Lõhnava kummeli seespidine kasutamine teekummeli asendajana: spasmolüütiline toime}

Lõhnava kummeli ja teekummeli õisikute ja ürdi spasmolüütilise toime uuringud teostati Tartu Ülikooli farmaatsia ja farmakoloogia kateedrite koostöös. Droogidest valmistati sarnaselt eelmise kirjeldatud katsega kolm vesitõmmist. Vesitõmmiste spasmolüütilise toime uurimine toimus loomkatsena rottidelt isoleeritud peensoole osadega (duodenum ja ileum), mida Tyrode'i lahuses pidevalt aereeriti. Etalonlõõgastuse tekitamiseks kasutati adrenaliinvesinikkloriidilahust kontsentratsiooni $10^{-6} \mathrm{M}$ saamiseks termostaadis, võrreldes tulemust etalonlõõgastuse vähenemisega protsentides.

Uuritud vesitõmmiste spasmolüütilise toime aktiivsus varieerus suurtes piirides (18-168\%). Lõhnava kummeli õisikute ja ürdi vesitõmmiste aktiivsus kõikus olenevalt tõmmise liigist vahemikes vastavalt $21-93 \%$ ja $53-119 \%$, rääkides seega ürdi kasuks. Ka teekummeli puhul osutus ürdist valmistatud vesitõmmiste spasmolüütiline aktiivsus (67-167\%) suuremaks kui õisikute vesitõmmiste vastavad näitajad (25-100\%). See võimaldab teha kaks järeldust. Esiteks, ürdist valmistatud vesitõmmiste spasmolüütiline aktiivsus on suurem kui õisikutel. See seletub arvatavasti rikkalikuma flavonoidide sisaldusega ürdis. Teiseks, lõhnava kummeli ürdi spasmolüütiline aktiivsus ei jää alla teekummeli ürdi vastavale toimele.

Need tulemused kinnitasid hüpoteesi, et teekummeli ja lõhnava kummeli õisikute asemel võiks kasutada nende ürti. Lõhnava kummeli spasmolüütiline 


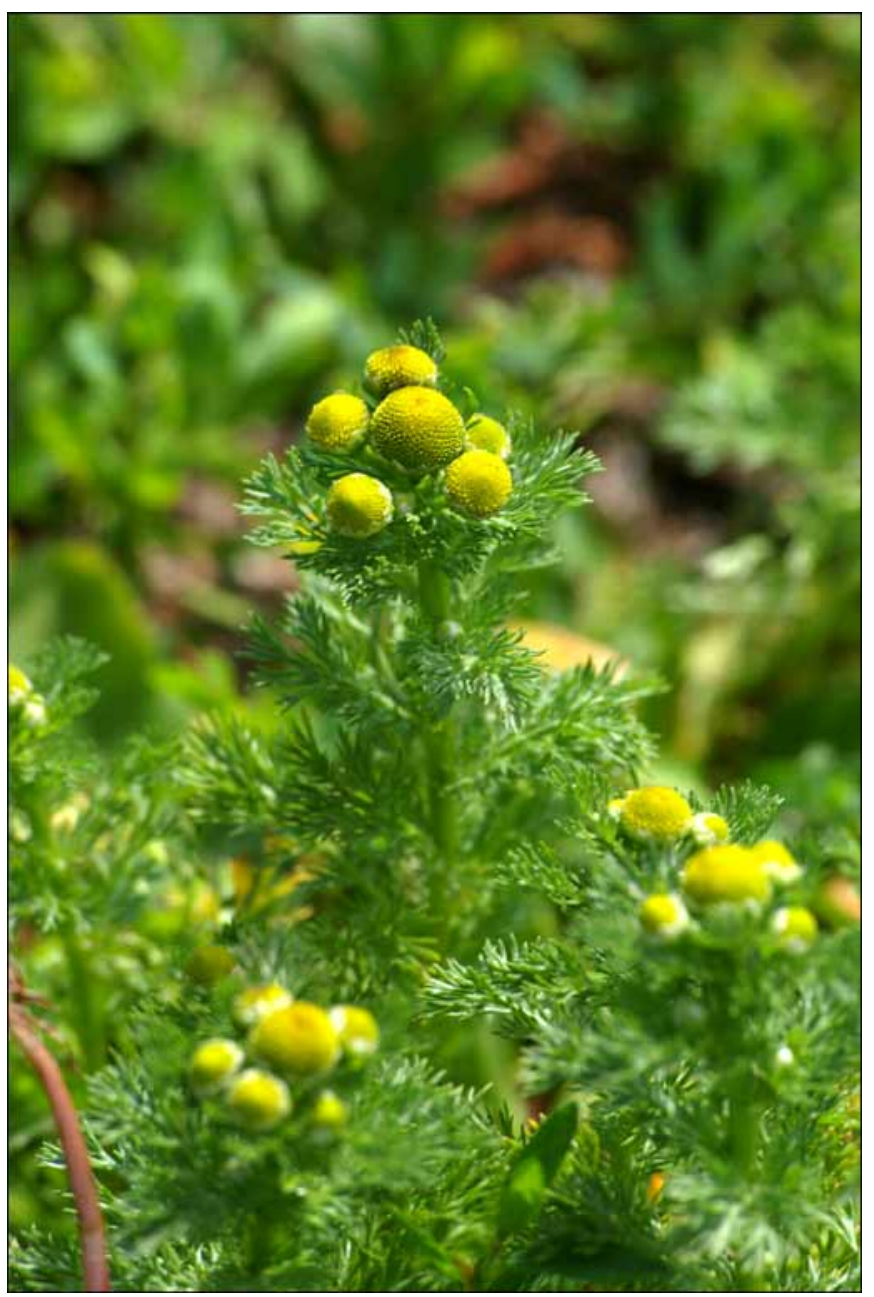

Foto 4. Lõhnav kummel. Ain Raali foto.

toime on samas suurusjärgus teekummeli vastava toimega ning lõhnav kummel võiks olla selles suhtes teekummeli asendaja (Raal \& Vilu \& Vahar \& Vilgas 1987).

\section{Lõhnava kummeli seespidine kasutamine teekummeli asendajana: kliiniline uuring}

Uurimaks kummelite toimet soolestiku düsfunktsioonidele teostati 1985. aastal Tartu Kliinilises Nakkushaiglas kliiniline uuring 30 täiskasvanud patsiendiga. Selleks valmistati lõhnava kummeli õisikutest ja ürdist ning tee- 
kummeli samadest taimeosadest tabletid - droog peenestati, sõeluti läbi $0,2 \mathrm{~mm}$ diameetriga avadega sõela ja granuleeriti. Granulaadist pressiti tabletid, mis ümbritseti maos lagunemise vältimiseks happekindla kattega. Uurimuse eesmärgiks oli kindlaks teha tablettide mõju spetsiifiliste ja mittespetsiifiliste enterokoliitide akuutsele staadiumile. Katsealustel hinnati kliinilist pilti, laboratoorsete analüüside tulemusi ja muutusi jämesoole alaosa limaskestal. Kuuele düsenteeriahaigele manustati kummelitablette kui ainukest ravivahendit kolm korda päevas enne sööki 4-5 päeva vältel. Uurimus näitas, et kummelipreparaadid omavad tõenäoliselt nii põletikuvastast kui ka antibakteriaalset toimet. Seejuures ei täheldatud erinevusi lõhnava kummeli ja teekummeli efektiivsuses.

Kuigi need esialgsed katsed hõlmasid vaid väheseid patsiente ja uuring oli disainitud mitte kõikidele tänapäeva nõuetele vastavalt (puudus platseeborühm), räägivad needki andmed lõhnava kummeli seespidise kasutamise võimalikkusest teekummeli asendajana (Arak \& Aasav \& Vahar \& Raal 1986).

\section{Lõhnava kummeli ürt versus õisikud: keemiline koostis}

Nagu ülaltoodust selgus, võiks lõhnavat kummelit kasutada ka seespidiselt ja seda just ürdi kujul teekummeli asendajana. Seda võimaldavad väita eelmainitud bioloogilised uuringud. Ent vaatame ka nende droogide keemilist koostist.

Leedus kasvava lõhnava kummeli õisikute, lehtede ja varte analüüsil on eeterliku õli kvantitatiivseks sisalduseks saadud vastavalt $0,21-0,23 \%, 0,14 \%$ ja $0,03 \%$ (Jaskonis 1978). Permi oblastis tehtud uurimused näitasid, et lõhnava kummeli õisikutes sisaldub $0,25-0,56 \%$, lehtedes $0,29-0,51 \%$ ja vartes 0,09 $0,13 \%$ eeterlikku õli. Autorid näitasid ühtlasi, et lõhnava kummeli ürt vastab eeterliku õli sisalduse poolest N Liidu farmakopöa (NLF 1968) ja GOSTi (ГОCT 2237-75) nõuetele (mitte vähem kui 0,2\%) (Prossovski \& Oleško et al. 1984). Maapealses osas sisaldus eeterlikku õli vahemikus $0,2-0,3 \%$, mis samuti vastab mainitud normatiivtehnilise dokumentatsiooni nõuetele. Ühtlasi oli ürdis märkimisväärselt kõrge eeterliku õli põhikomponentide sisaldus: mürtseeni leidus õisikutes ja ürdis sõltuvalt kasvukohast vastavalt 6,4$23,2 \%$ ja $0,9-28,2 \%$, $\beta$-farneseeni $12,5-39,5 \%$ ja $22,1-34,2 \%$, geranüülisovaleraati $14,1-42,9 \%$ ja $5,7-43,6 \%$ ning cis-en-in-bitsükloeetrit $18,2-49,1 \%$ ja $11,2-49,4 \%$. Uuringute tulemusena soovitasid need autorid esimestena N Liidus kasutada lõhnava kummeli õisikute asemel ürti (Oleško \& Prossovski 1986). 
Eestis kasvava lõhnava kummeli õisikute, lehtede ja varte eeterliku õli sisalduse võrdlev analüüs näitas, et õisikute kasutamisel saaks ühel ruutmeetril kasvavatelt taimedelt $0,27-0,33 \mathrm{ml}$ eeterlikku õli. Lehtedel ja vartel on need näitajad vastavalt $0,09-0,37 \mathrm{ml} / \mathrm{m}^{2}$ ja $0,05-0,14 \mathrm{ml} / \mathrm{m}^{2}$. Kui need tulemused avaldada protsentides, moodustab õisikutest saadud eeterlik õli 39$70 \%$ kõikidest uuritud taimeosadest saadud eeterlikust õlist. Oluline kogus eeterlikust õlist sisaldub siiski ka lehtedes (19-51\%) ja märkimisväärne osa ka vartes (10-26\%). Bioloogiliselt aktiivsete ainete sisaldust lõhnava kummeli erinevates osades võib muidugi väljendada ka individuaalsete ühendite (farneseen, farnesool, bisabolooloksiid A, en-in-bitsükloeeter, herniariin jt), mida õisikutes leidub 84-362 mg\%, lehtedes $61-322 \mathrm{mg} \%$ ja vartes $16-130 \mathrm{mg} \%$ (Arak \& Raal \& Tammeorg 1986). Edasiste uuringute käigus analüüsiti eeterliku õli komponentide, fenoolsete ühendite ja tanniinide sisaldust lõhnava kummeli õisikutes ja erineva pikkusega maapealsetes osades. Seejuures jõuti seisukohale, et otstarbekas ei ole kasutada mitte kogu maapealset osa, vaid lõhnava kummeli ladvaosa taime kõrguse pooles ulatuses (Arak \& Raal 1987).

\section{Lõhnava kummeli ürt versus teekummeli õisikud: keemiline koostis}

Teekummeli õisikutel ja lõhnava kummeli ürdil on lisaks sarnastele toimetele lähedane keemiline koostis. Järgnevalt vaatlemegi, mida fütokeemilistel uuringutel selles suhtes väita on.

Nagu ülalpool juba mainitud, ei sisalda lõhnava kummeli eeterlik õli teekummeli eeterliku õli üht iseloomulikku komponenti - põletikuvastase toimega hamasuleeni. Tegelikult pole uurijad selles küsimuses päris ühel meelel. Nii on hamasuleeni leitud 1960. aastal Ungaris kasvava lõhnava kummeli õisikutes, kusjuures autorid näitasid, et asuleenide tüüpi ühendite sisaldus sõltub kasvukohast (Máthé \& Tyihák 1960). 1970. aastatel Leedus kasvava lõhnava kummeli analüüsimisel leiti õisikutest hamasuleeni jälgedes, teised taimeosad seda ühendit ei sisaldanud (Jaskonis 1978). Põhjalikumalt tegelesid hamasuleeni sisaldumise või puudumise uurimisega nõukogude teadlased (Kisseljova \& Kibaltšitš 1970), kes selles taimes hamasuleeni siiski ei leidnud. Eeterlikku õli saadi nende poolt kuni 0,5\% ja hamasuleeni puudumisele viitas juba õli rohekas värvus (hamasuleen värvib selle siniseks). Olgu mainitud, et kõikide meie poolt destilleeritud lõhnava kummeli eeterlikel õlidel on sinine värvus puudunud. Äsja mainitud venelaste uuringud 
lubasid oletada, et hamasuleeni sisaldus sõltub lõhnava kummeli kasvukohast. Selle hüpoteesi kontrollimiseks viisime läbi uurimuse, milles analüüsisime Eestist, Lätist ja Leedust kogutud lõhnava kummeli õisikuid. Droogiproove oli ühtekokku 30 ja ükski neist ei sisaldanud hamasuleeni (Raal 1989a: 82-87). Kuivõrd aga hamasuleen tekib eeterlikus õlis alles selle destillatsiooni käigus, ei mõjusta tema puudumine lõhnavas kummelis eeterlikku õli mittesisaldavate preparaatide, sh laialdaselt kodusel teel valmistatavate vesitõmmiste toimet.

Mõlema kummeli õisikutes on kindlaks tehtud ühed ja samad flavonoidid (kvertsimeritriin, apigeniin, luteoliin ja gossipitriin) ning aromaatsed happed (klorogeen-, kohv-, feerula-, vanilliin-, protokatehool-, o-kumaar- ja sirelhape) (Tšetvernja 1986). Mõlemas kummelis on teisigi sarnaseid fenoolseid ühendeid (Prossovski 1986).

Andmed mõningate bioloogiliselt aktiivsete ainete sisalduse kohta lõhnava kummeli õisikutes ja ürdis ning teekummeli õisikutes on toodud tabelis 2 . Selgub, et mõlema kummeli eeterliku õli kvalitatiivseks erinevuseks on vaid bisabolooli ja hamasuleeni puudumine lõhnavas kummelis, samas kui lõhnav kummel sisaldab erinevalt teekummelist geranüülisovaleraati. Et sarnaselt hamasuleenile toimib ka bisabolool põletikuvastaselt, räägib see teekummeli kasuks. Teised eeterliku õli komponendid leiduvad mõlemas kummelis, kuid üsna erinevates kogustes. Nii on teekummeli eeterlikule õlile iseloomulikum kõrgem bisabolooli derivaatide sisaldus, lõhnava kummeli eeterlikus õlis seevastu on tunduvalt rohkem spasmolüütilise toimega en-in-bitsükloeetri kahte isomeeri. Ka kumariinide kõrgem sisaldus lõhnavas kummelis räägib selle taime oletatavalt tugevama spasmolüütilise toime kasuks. Keemilise koostise võrdlev uuring lubab aga prognoosida, et põhitoimed (põletikuvastane ja spasmolüütiline) on mõlemal kummelil ühed ja samad.

Kui aga võrrelda erinevate toimeainete sisaldust lõhnava kummeli õisikutes ja ürdis, siis sisaldavad mõlemad droogid eeterliku õli komponentidest praktiliselt võrdsel määral trans- $\beta$-farneseeni, geranüülisovaleraati ning cisja trans-en-in-bitsükloeetrit. Farnesooli ja bisabolooloksiid A sisalduselt jääb ürt õisikutele siiski alla. Sama võib öelda nii individuaalsete kumariinide kui ka kumariinide summa kohta, mida leidub rohkem õisikutes. Seevastu sisaldub nii taime ürdis kui ka õisikutes ühesuguses suurusjärgus flavonoide. Eeterliku õli komponentide üldsisalduselt jääb lõhnava kummeli ürt mõnevõrra teekummeli õisikutele alla, samas suurusjärgus on aga kumariinide ja flavonoidide sisaldus. Seega viitavad fütokeemiliste analüüside tulemused lõhnava kummeli ürdi kasutamise võimalikkusele teekummeli õisikute asendajana. 
Tabel 2. Terpenoidide, kumariinide ja flavonoidide sisaldus lõhnava kummeli õisikutes ja ürdis ning teekummeli ürdis (Raal 1989b: 11)

\begin{tabular}{|c|c|c|c|}
\hline \multirow[t]{2}{*}{ Koostisained } & \multicolumn{3}{|c|}{ Sisaldus, mg\% } \\
\hline & $\begin{array}{l}\text { Lõhnava } \\
\text { kummeli õisikud }\end{array}$ & $\begin{array}{l}\text { Lõhnava } \\
\text { kummeli ürt }\end{array}$ & $\begin{array}{l}\text { Teekummeli } \\
\text { oisikud }\end{array}$ \\
\hline \multicolumn{4}{|c|}{ Terpenoidid } \\
\hline trans- $\beta$-farneseen & $167,8 \pm 12,5$ & $170,6 \pm 14,1$ & $149,1 \pm 11,7$ \\
\hline Farnesool & $30,6 \pm 2,4$ & $8,3 \pm 0,1$ & $9,6 \pm 0,6$ \\
\hline Geranüülisovaleraat & $99,3 \pm 6,7$ & $97,6 \pm 6,3$ & Ei sisalda \\
\hline Bisabolooloksiid A & $8,4 \pm 0,8$ & $1,5 \pm 0,1$ & $35,1 \pm 2,6$ \\
\hline $\begin{array}{l}\text { cis-en-in-bitsüklo- } \\
\text { eeter }\end{array}$ & $157,8 \pm 13,5$ & $140,0 \pm 10,7$ & $69,8 \pm 4,0$ \\
\hline $\begin{array}{l}\text { trans-en-in-bitsüklo- } \\
\text { eeter }\end{array}$ & $44,5 \pm 3,9$ & $37,8 \pm 1,6$ & $10,2 \pm 0,8$ \\
\hline Spatulenool & Jälgedes & Jälgedes & $12,4 \pm 0,8$ \\
\hline Bisabolool & Ei sisalda & Ei sisalda & $102,1 \pm 7,3$ \\
\hline Bisabolooloksiid B & Jälgedes & Jälgedes & $49,3 \pm 2,9$ \\
\hline Bisaboloonoksiid A & Jälgedes & Jälgedes & $221,7 \pm 17,5$ \\
\hline Hamasuleen & Ei sisalda & Ei sisalda & Jälgedes \\
\hline Terpenoidide summa & $508,4 \pm 20,1$ & $455,8 \pm 18,6$ & $659,3 \pm 23,0$ \\
\hline \multicolumn{4}{|c|}{ Kumariinid } \\
\hline Herniariin & $280,7 \pm 11,0$ & $209,8 \pm 6,6$ & $119,5 \pm 6,8$ \\
\hline Umbelliferoon & $120,2 \pm 11,9$ & $81,2 \pm 8,9$ & $40,7 \pm 3,3$ \\
\hline Kumariinide summa & $568,3 \pm 33,1$ & $350,6 \pm 28,4$ & $374,5 \pm 26,0$ \\
\hline \multicolumn{4}{|c|}{ Flavonoidid } \\
\hline Tsinarosiid & $198,6 \pm 15,0$ & $214,3 \pm 16,6$ & $103,6 \pm 9,2$ \\
\hline $\begin{array}{l}\text { Apigeniin-7-O-glüko- } \\
\text { siid }\end{array}$ & Jälgedes & Jälgedes & Jälgedes \\
\hline Kvertsimeritriin & Jälgedes & Jälgedes & Jälgedes \\
\hline Flavonoidide summa & $473,2 \pm 43,1$ & $517,8 \pm 48,4$ & $530,0 \pm 45,1$ \\
\hline
\end{tabular}

Hilisemaaegsetes fütokeemilistes uuringutes on analüüsitud Eestis kasvava lõhnava kummeli eeterliku õli koostist gaasikromatograafiliselt kapillaarkolonniga, mis võimaldas kindlaks teha ühtekokku 26 komponenti (Orav \& Kailas \& Kann 1999). Sama metoodikat kasutades uuriti lähiaastatel teekummeli õisikute eeterliku õli koostist, milles tehti kindlaks 38 koostisainet (Raal \& Arak \& Orav \& Ivask 2003). Seejuures sisalduvad mõlema kummeli eeterlikus õlis ühiste komponentidena linalool, $\alpha$-pineen, mürtseen, 1,8-tsineool, $\beta$-bisaboleen, trans- $\beta$-farneseen, $\alpha$-bisabolool, hamasuleen, spatulenool, bisaboloonoksiid A, bisabolooloksiid B, germakreen D ning cis- ja trans-en- 
in-bitsükloeeter. Needki andmed räägivad mõlema kummeli eeterliku õli koostise suhtelisest sarnasusest. Kanadas kasvava lõhnava kummeliga tehtud uuringutes suudeti selle taime eeterlikus õlis kindlaks teha $36 \mathrm{kom}$ ponenti (Lopes \& Kolodziejczyk 2005). See arv on väga lähedane teekummelis leitud ülalmainitud ainete hulgaga.

\section{Kokkuvõte}

Teadusmeditsiini uuringutes kinnitust leidnud kummelite antimikroobne, spasmolüütiline ja põletikuvastane toime katavad vaid osa etnofarmakoloogias kajastatavast. Nagu eespool mainitud, tunnustatakse tänapäeval ka kummelite haavade paranemist soodustavat toimet (Blumenthal 2000: 59). See on ühelt poolt seotud antimikroobse ja põletikuvastase efektiga, kuid oma osa on siin kindlasti ka eeterliku õli komponendil farneseenil, mis soodustab kudede taastumist. Raskesti paranevate haavade tohterdamisest kummelitega räägivad ka esivanemate kogemused. Sama võiks öelda kummeli soodsa mõju kohta nahale, mis jääb juba kosmeetika valdkonda.

Kas rahvameditsiin on tõesti põhjatu varasalv ja teadusmeditsiinil jääb üle kõik selle sügavustes peituv vaid üle võtta? See kõlab liiga ilusti, et olla tõsi. Näiteks üpris arusaamatuks jääb kummelite kasutamine etnomeditsiinis mitmesuguste valude korral. Muidugi võib seda toimet seletada kaudse mehhanismiga (põletikuvastane, diureetiline, spasme lõõgastav jm), kuid otseselt anesteseeriv ja analgeetiline toime kummelitel puudub. Kindlasti ei saa kummelis näha ka tuberkuloosi- või kollatõveravimit. Seevastu kummel (eriti lõhnav kummel) kui ussiajati näib olevat etnofarmakoloogiale tundmatu.

Eesti etnofarmakognoosia elujõud on alles ning vähemasti kummelite puhul töötavad esivanemate kogemused ja teadusuuringutest sündiv teadmine üllatavalt edukalt käsikäes. See annab alust ja julgust kasutada farmakognostiliste, fütokeemiliste ja farmakoloogiliste uuringute planeerimisel rahvameditsiinis talletatut ka teiste ravimtaimede puhul. Seejuures etnomeditsiin ei dikteeri ja ei pea ega õigupoolest tohigi meile midagi dikteerida, küll aga annab ideid uuringuteks. Ideed saavad aga genereeruda keskkonnas, kus eksisteerib piisavalt teaduslikke teadmisi ja uurimisvõimalusi. Filosoofilises mõttes on etnofarmakognoosia ja farmakognoosia seega vastandid, mis teineteist ei välista. Ehk tuntud lauset parafraseerides: kes minevikku ei mäleta, elab tulevikus mõttetult suurt vaeva nähes. 


\section{Kommentaarid}

${ }^{1}$ Meteorismivastane - soolegaaside suurenenud hulka vähendav.

${ }^{2}$ Granulatsioon - sidekoe regeneratsioon, noore sidekoe teke.

${ }^{3}$ Anafülaktiline šokk - äge ülitundlikkusreaktsioon.

${ }^{4}$ Fungitsiidne - seeni hävitav.

${ }^{5}$ Solubilisaat -vee, eeterliku õli ja pindaktiivse aine segamisel saadud näiline lahus.

6 Matseraadid - toatemperatuuril tehtud droogitõmmised veega.

${ }^{7}$ Agregatsioon - antud kontekstis mikroobide üksteisega liitumine.

\section{Arhiiviallikad}

EKnS = Eesti Kirjanduse Seltsi käsikirjaline rahvaluulekogu, 1871-1891.

ERA = Eesti Rahvaluule Arhiivi käsikirjaline rahvaluulekogu, 1927-1944.

RKM = Eesti TA Fr. R. Kreutzwaldi nim (Riikliku) Kirjandusmuuseumi (nüüd Eesti Kirjandusmuuseumi) rahvaluule osakonna rahvaluulekogu, 1945-1995.

\section{Kirjandus}

Abramzon \& Gajevoi 1979 = Абрамзон, Ариэль А. \& Гаевой Г. М. (toim). Поверхностноактивные вещества: Справочник. Ленинград: Химия.

Aggag, M. E. \& Yousef, R. T. 1972. Study of Antimicrobial Activity of Chamomile Oil. Planta Medica 22: 2, lk 140-144.

Albath, Wolfgang 1939. Entzündungswidrige Stoffe im Kamillenöl. Nauny-Schmiedebergs Archiv für experimentelle Pathologie und Pharmakologie 193, lk 619-621.

Annuk, Heidi 1998. Mõnede ravimtaimede vesitõmmiste toimest Escherichia coli ja Helicobacter pylori suhtes in vitro. Magistriväitekiri. Tartu: Tartu Ülikooli arstiteaduskonna Farmaatsia Instituut.

Annuk, Heidi 2002. Selection of Medicinal Plants and Intestinal Lactobacilli as Antimicrobial Components for Functional Foods. Dissertationes medicinae universitatis Tartuensis 73. Tartu: Tartu Universtity Press.

Arak 1980 = Арак, Эльмар. Химико-фармакогностическое изучение ромашки аптечной выращиваемой в Эстонской ССР. Диссертация на соискание ученой степени кандидата фармацевтических наук. Тарту.

Arak 1981 = Арак, Эльмар. Химико-фармакогностическое изучение ромашки аптечной выращиваемой в Эстонской ССР. Автореферат диссертации на соискание ученой степени кандидата фармацевтических наук. Ленинград. 
Arak \& Aasav \& Vahar \& Raal 1986 = Арак, Эльмар \& Аазав, Йоел \& Вахар, Вамбо \& Раал, Айн. О лечении дисфункции кишечника препаратами ромашки. Успехи медицинской науки: тезисы докладов научной конференции, Тарту, 9. Тарту: Тартуский государственный университет, lk 161-162.

Arak \& Jents \& Siirde 1973 = Арак, Эльмар \& Йентс, Арвед \& Сийрде, Эльмар. О действии солубилизированного эфирного масла ромашки аптечной при лечении воспалений верхних дыхательных путей. Сийрде, Эльмар (toim). Труды Vнаучно-практической конференции оториноларингологов Эстонской ССР, посвященной 80-летию основания оториноларингологии в Эстонской ССР: 21-22 июня 1973 года в Тарту. Таллинн: Министерство здравоохранения Эстонской ССР, lk 149-150.

Arak \& Jents \& Tammeorg 1974 = Арак, Эльмар \& Йентс, Арвед \& Таммеорг, Йоаннес. Препарат для ингаляции, содержащий эфирное масло ромашки. Муравьев, Иван А. (toim). Материалы Второго Всесоюзного съезда фармацевтов: Рига, 17-20 сент. 1974 г. Рига: Всесоюз. науч. о-во фармацевтов, lk 271-272.

Arak \& Raal 1987 = Арак, Эльмар \& Раал, Айн. О восможности использования надземной части Matricaria dioscoidea DC. в качестве лекарственного сыря. Растительные ресурсы 23: 4, lk 584-590.

Arak \& Raal \& Tammeorg 1986 = Арак, Эльмар \& Раал, Айн \& Таммеорг, Йоаннес. Трава ромашки душистой - заменитель цветков ромашки аптечной. Фармация $35: 4,1 \mathrm{k}$ $19-22$.

Arak, Elmar \& Raal, Ain \& Vahar, Vambo \& Lääne, Küllike \& Taul, Piret 1986. Kummeli vajadus ja varumine. Nõukogude Eesti Tervishoid 29: 3. lk 188-190.

Arnold, H. \& Jung, Friedrich \& Reuber, R. \& Spielmann, W. 1949. Synthetische Azulene mit entzündungswidriger Wirkung. Die Pharmazie 4: 220.

Barnes, Joanne \& Anderson, Linda A. \& Phillipson J. David 2002. Herbal Medicines: A Guide for Healthcare Professionals. 2. tr. Chicago, London: Pharmaceutical Press.

Bisset, Norman Grainger \& Wichtl, Max 1994. Herbal Drugs and Phytopharmaceuticals: A Handbook for Practice on a Scientific Basis. Stuttgart: Medpharm Scientific Publishers \& Boca Raton: CRC Press.

Blumenthal, Mark 2000. Herbal Medicine: Expanded Commission E Monographs. IntegrativMedicine. [S.l.]: American Botanical Council.

Bogs, Ulrich \& Meinhard, Joachim 1955. Zur Herstellung von Kamillen-Fluidextrakt. Die Pharmazie 10: 11, lk 653-658.

Breinlich, Josef 1966. Zur Chemie und Pharmakologie der En-In-Dicycloäther der Matricaria chamomilla. Deutsche Apotheker-Zeitung 106: 20, lk 698-699.

Breinlich, Josef \& Scharnagel, Klaus 1968. Pharmakologische Eigenschaften des EnIn-Dicycloäthers aus Matricaria chamomilla. Arzneimittel-Forschung 18: 4, lk 429431.

Brock, Norbert \& Kottmeier, Jutta \& Lorenz, Dietrich \& Veigel, Helmut 1954. Zur Frage der antiphlogistischen Wirkung von Azulenen im Tierversuch. Naunyn-Schmiedebergs Archiv experimentelle Pathologie und Pharmakologie 223: 5, lk 450-464. 
Bunney, Sarah (toim) 1993. The Illustrated Encyclopedia of Herbs: Their Medicinal and Culinary Uses. Prague: Chancellor Press.

Eesti taimede määraja 1999. Leht, Malle (toim). Tartu: Eesti Loodusfoto.

Ellö, I. 1962. Beiträge zur Löslichkeitsvermittlung durch Twens 2: Mitteilung: Solubilisation ätherischer Öle und Ölbestandteile. Die Pharmazie 17: 8, lk 44-446.

European Pharmacopoeia 2005. 5. väljaanne. Strasbourg: Council of Europe.

Gava \& Janku 1957 = Гава, М. \& Янку, Иво 1957. О фармакологических свойствах ромашки и можжевельника. Чехословатское медицинское обозрение $3: 2,1 \mathrm{k}$ 129-137.

GOSR 1977 = Государственный реестр лекарственных средств, разрешенных для применения в медицинской практике и к промышленному производству по состоянию на $1 / 1$ 1977 г. Р-1. Москва: Мин. Здрав. СССР 2606; 72/267/33.

Habersang, Silke \& Leuschner, Fred \& Isaac, Otto \& Thiemer Klaus 1979. Pharmakologische Untersuchungen von Kamillen-Inhaltsstoffen IV: Untersuchungen zur Toxizität des (-)-a-Bisabolols. Planta Medica 37: 2, lk 115-123.

Isaac, Otto 1975. Fortschritte in der Kamillenforschung. Physikalische Medizin und Rehabilitation 16: 11, lk 223-229.

Isaac, Otto 1979. Pharmakologische Untersuchungen von Kamilleninhaltsstoffen 1: Zur Pharmakologie des (-)-a-Bisabolols und der Bisabololoxide (Übersicht). Planta Medica 35, lk 118-124.

Jakovlev \& Blinova 1996 = Яковлев, Геннадий П. \& Блинова, Клавдия Ф. Растения для нас: Справочное издание. Санкт-Петербург: Учебная книга.

Jakovlev \& Blinova 2004 = Яковлев, Геннадий П. \& Блинова, Клавдия Ф. (toim). Лекарственное растительное сырье. Фармакогнозия. Санкт-Петербург: СпецЛит.

Jakovlev, Vladimir 1975. Pharmakologisch-toxikologische Untersuchungen mit einigen Kamillenwirkstoffen. Demling, Ludwig \& Nasemann, Theodor (koost \& toim). Erfahrungstherapie - Späte Rechtfertigung: Internationales Symposium, Wien 1975. Karlsruhe: Verlag G. Braun, lk 67-69.

Jakovlev, Vladimir \& Isaac, Otto \& Thiemer, Klaus \& Kunde, R. 1979. Pharmakologische Untersuchungen von Kamillen-Inhahaltsstoffen II: Neue Untersuchungen zur antiphlogistischen Wirkung des (-)-a-Bisabolols und der Bisabololoxide. Planta Medica 35, lk 125-140.

Jakovlev, Vladimir \& Schlichtegroll, Ansgar von 1969. Zur entzündungshemmenden Wirkung von (-)-a-Bisabolol, einem wesentlichen Bestandteil des Kamillenöls. Arsneimittel-Forschung 19: 4, lk 615-616.

Janku, Ivo \& Zita, Č. 1954. Protizánětlivě účinky některých látek z heřmánku II. Československá Farmacie 3: 3, lk 93-95.

Jaretzky, Robert \& Neuwald, Fritz 1939. Comparative Pharmacological Tests on Oils of Matricaria chamomilla L. and Matricaria discoidea L. Archiv der Pharmazie 277, lk 50-53. 
Jaskonis 1978 = Ясконис, Юозас А. 1978. Прорастание семянок ромашки пахучей, влияние минеральных удобрений на ее рост и содержание эфирного масла в органах в условиях Литовской ССР. Труды АН ЛитССР. Серия В. Биол. Науки 2, lk 51-57.

Jeličić-Hadžović, J. von \& Stern, P. 1972. Azulene und Bradykinin. Arzneimittel-Forschung 22: 7, lk 1210-1211.

Jents, Arved \& Arak, Elmar 1977a. Inhalation Therapy with Etherial Oil of Chamomile. 2nd Congress of International Society for Aerosols in Medicine (IGAeM), Warszawa, 20.-22. IV 1977, Abstract 15.

Jents \& Arak 1977b = Йентс, Арвед \& Арак, Эльмар. Электроаэрозольтерапия с эфирным маслом ромашки. Тезисы 3-й Всес. конф. по аэрозолям. Ереван, октябрь 1977, секции: медицинская, аэрозольные баллоны, $1 \mathrm{k}$ 27-28.

Jents \& Arak 1978 = Йентс, Арвед \& Арак, Эльмар. Использование ромашки при ингаляционной терапии. Тезисы докл. IV республ. н.-практ. конф. оториноларингологов Латв. ССР Современные аспекты оториноларингологии. Рига.

Jung, Friedrich \& Wendler, M. 1953. Über die Azulenvorstufen der Kamille. Die Pharmazie 8: 2, lk 117-120.

Kienholz, Manfred 1963. Beeinflussung bakterieller Toxine durch Kamillen- und Meerrettich-Inhaltsstoffe. Arzneimittel-Forschung 13: 9, lk 768-771; 13: 10, lk 920-927; 13: 11, lk 980-986; 13: 12, lk 1109-1119.

Kisseljova \& Kibaltšitš 1970 = Киселева, Е. Я. \& Кибальчич, П. Н. 1970. О ромашке душистой (Matricaria matricarioides (Less.) Porter). Фармация 20: 3, lk 70-71.

Kljujev \& Babajan $1979=$ Клюев, М. А. \& Бабаян, Эдуард А. (toim). Лекарственные препараты, разрешенные к применению в СССР. Москва: Медицина.

Kraul, Martin Alexander \& Schmidt, F. 1955. Über die antiarthritische Wirksamkeit eines Extraktes aus Flores Chamomillae. Zeitschrift für gesammte Innere Medizin und ihre Grenzgebiete 10: 19, lk 934-935.

Kraul, Martin Alexander \& Schmidt, F. 1957. Über die wachstumshemmende Wirkung bestimmter Extrakte aus Flores Chamomillae und eines synthetischen Azulenpräparates auf experimentelle Mäusetumoren. Archiv der Pharmazie 290/62: 2, lk 66-74.

Ljungh, Åsa \& Brown, A. \& Wadström, Torkel 1985. Surface Hydrophobicity of Coagulase Negative Staphylococci Determined by Salt Aggregation Test (SAT). Suttgart \& New York: Gustav Fischer Verlag.

Lopes, Daise \& Kolodziejczyk, Paul P. 2005. Essential Oil Composition of Pineappleweed (Matricaria discoidea DC.) grown in Canada. Journal of Essential Oil-Bearing Plants 8: 2, lk 178-182.

Máthé, Imre \& Tyihák, Ernő 1960. Adatok a Matricaria matricarioides (Less.) Porter hazai elterjedéséhez és hatóanyag vizsgilatịhoz. Acta Pharmaceutica Hungarica 32: 1, lk 43-48.

Muravjova 1981 = Муравьева, Дария А. Фармакогнозия. 2. tr. Москва: Медицина. 
Muravjova \& Samõlina \& Jakovlev 2002 = Муравьева, Дария А. \& Самылина, Ирина А. $\&$ Яковлев, Геннадий П. Фармакогнозия. Учебная литература для студентов фармацевтических вузов. Москва: Медицина.

Nasemann, Theodor \& Menzel, I. 1975. Kamillosan in der Dermatologie. Demling, Ludwig \& Nasemann, Theodor (koost \& toim). Erfahrungstherapie - Späte Rechtfertigung: Internationales Symposium, Wien 1975. Karlsruhe: Verlag G. Braun.

NLF 1968 = Государственная фармакопея СССР. 10. tr. Москва: Медицина.

NLF 1990 = Государственная фармакопея СССР 2. 11. tr. Москва: Медицина.

Oettel, Hansjürgen \& Wilhelm-Kollmannsperger, G. 1955. Zur Frage der antiphlogistischen Wirkung von Azulenen I: Mitt. Archiv für experimentelle Pathologie und Pharmakologie 226, lk 473-485.

Oettel, Hansjürgen \& Wilhelm-Kollmannsperger, G. 1956. Zur Frage der antiphlogistischen Wirkung von Azulenen II: Mitt. Archiv für experimentelle Pathologie und Pharmakologie 228: 4, lk 331-339.

Oleško \& Prossovski 1986 = Олешко, Г. И. \& Просовский, М. А. Динамика содержания эфирного масла и его главных компонентов у Matricaria discoidea DC. Растительные ресурсы 22: 3, lk 377-382.

Orav, Anne \& Kailas, Tiiu \& Kann, Jüri 1999. Volatile Constituents of Matricaria matricarioides (Less.) Port. Journal of Essential Oil Research 11: 2, lk 243-245.

Pommer, Charlotte 1942. Über die Wirkung einiger Azulene bei Entzündungen. Naunyn-Schmiedebergs Archiv für experimentelle Pathologie und Pharmakologie 199: 1, $1 \mathrm{k} 74-82$.

Prossovski 1986 = Просовский, М. А.. Фармакогностическое изучение ромашки душистой. Автореферат диссертации на соискание ученой степени кандидата фармацевтических наук. Харьков.

Prossovski \& Oleško et al. $1984=$ Просовский, М. А. \& Олешко, Г. И. \& Сюзева, З. Ф. \& Мельникова, О. А. \& Евтихеева, О. В. К рациональному использованию ромашки ромашковидной [Matricaria matricarioides (Less.) Porter]. Фармация 33: 4, lk 28-30.

Raal, Ain 1982. Kummel Eesti rahvameditsiinis. Referatiivne võistlustöö. Tartu: Tartu Riiklik Ülikool, farmaatsia kateeder.

Raal, Ain 1987. Lõhnav kummel eesti rahvameditsiinis ja teadusuuringutes. Noored filoloogias 1987: noorteadlaste konverents 8. ja 9. dets.: teesid 2: Rahvaluule ja etnograafia. Tallinn: ENSV TA Keele ja Kirjanduse Instituut, lk 23-27.

Raal 1989a = Раал, Айн. Фитохимическое изучение ромашки душистой в Эстонии. Диссертация на соискание ученой степени кандидата фармацевтических наук. Ленинград.

Raal $1989 \mathrm{~b}=$ Раал, Айн. Фитохимическое изучение ромашки душистой в Эстонии. Автореферат диссертации на соискание ученой степени кандидата фармацевтических наук. Ленинград.

Raal, Ain \& Arak, Elmar \& Orav, Anne \& Ivask, Kairi 2003. Comparison of Essential Oil Content of Matricaria recutita L. from Different Origins. Ars Pharmaceutica 44: $2,1 \mathrm{k} 159-165$. 
Raal, Ain \& Arak, Elmar \& Rekand, Elen \& Bender, Lauri 1998. Droogide vajadusest Eesti vabamüügiapteekides. Eesti Rohuteadlane 2, lk 3-6.

Raal \& Rooma 1988 = Раал, Айн \& Роома, Маарья. Определение DL эфирного масла ромашки душистой. Наука на страже здоровья 2: Тезисы научной конореренции 20 окт. 1988 г. Тарту: Тартуский государственный университет, lk 334-335.

Raal, Ain \& Sõukand, Renata 2005. Classification of Remedies and Medicinal Plants of Estonian Ethnopharmacology. Trames 9 (59/54): 3, lk 259-267.

Raal, Ain \& Vilu, Ülle \& Vahar, Vambo \& Vilgas, Malle 1987. Mõningate triibus Anthemideae taimede vesitõmmiste spasmolüütilisest toimest. Eksperimentaalbioloogia 2: Noorte teadlaste konverentsi (Harku, 20. nov. 1987. a.) teesid. Harku: Eesti NSV Teaduste Akadeemia, lk 64-71.

Samuelsson, Gunnar 1992. Drugs of Natural Origin. Stockholm: Swedish Pharmaceutical Press.

Santesson, Carl Gustaf 1925. Action of Matricaria discoidea and M. chamomilla. Pharmazeutische Zentralhalle fuer Deutschland 66, lk 829-831.

Schmialek, P. 1961. Die Identifizierung zweier im Tenebriokot und in Hefe vorkommender Substanzen mit Juvenilhormonwirkung. Zeitschrift für Naturforschung 16b: 7, lk 461-464.

Schmidt, K. L. 1954. Die Wirkung des 1,4-Dimethyl-7-isopropylazulen gegen Strahlenschäden bei Röntgentherapie. Strahlentherapie 94: 2, lk 270-271.

Szalontai, M. \& Verzárné-Petri, G. \& Florian, E. 1976. Adatok a Matricaria chamomillae L. biológiailag aktiv kompenenseinek antifungialis hatásáhos. Acta Pharmaceutica Hungarica 46: 5-6, lk 232-247.

Szelenyi, Istvan \& Isaac, Otto \& Thiemer, Klaus 1979. Pharmakologische Untersuchungen von Kamillen-Inhaltsstoffen III: Tierexperimentelle Untersuchungen über die ulkusprotektive Wirkung der Kamille. Planta Medica 35: 3, lk 218-227.

Stern, P. \& Milin, R. 1956. Die antiallergische und antiphlogistische Wirkung der Azulene. Arzneimittel-Forschung 6: 8, lk 445-450.

Stern, P. \& Milin, R. 1957. Pharmakologie der Azulene. Therapeutische Umschau und medizinische Bibliographie 14: 11, lk 308-310.

Zita, Č. 1955. Vliv čistých látek heŕmánkové silice na tepelné popáleniny. Časopis lekařŭ českých, 94: 8, lk 203-208.

Tammeorg, Johannes \& Kook, Oskar \& Vilbaste, Gustav 1984. Eesti NSV ravimtaimed. 5., täiend \& parand tr. Tallinn: Valgus.

Thiemer, Klaus \& Stadler, Richard \& Isaac, Otto 1972. Biochemische Untersuchungen von Kamillen-Inhaltsstoffen I: Antipeptische Wirkung von Kamillenextrakt und 1,4dimethyl-7-isopropylazulensulfonsaurem Natrium. Arzneimittel-Forschung 22: 6, lk 1086-1087.

Tšetvernja 1986 = Четверня, С. А. Сравнительное изучение фенолов соцветий двух видов Matricaria L. Растительные ресурсы 22: 3, lk 373-377. 
Turova 1974 = Турова, Антонина Д. Лекарственные растения СССР и их применение. Москва: Медицина.

Turova \& Sapožnikova \& Ven Dõok Li 1987 = Турова, Антонина Д. \& Сапожникова, Эмилия Н. \& Вьен Дыок Ли. Лекарственные растения СССР и Вьетнама. Москва: Медицина.

Tuszek, H. 1953. Beitrag zur Behandlung von Allergosen. Medizinische Klinik 47, lk 1744-1745.

Türi, Endel \& Türi, Mall \& Annuk, Heidi \& Arak, Elmar 1999. Action of aqueous extracts of bearberry and cowberry leaves and wild camomile and pineapple-weed flowers on Escherichia coli surface structures. Pharmaceutical Biology 37: 2, lk 127-133.

Verzárné-Petri, G. \& Szegi, J. \& Marczal, G. 1979. Adatok a kamilla agyes vegyületeinek hatisihoz. Acta Pharmaceutica Hungarica 49: 1, lk 13-20.

Vilbaste, Gustav 1993. Eesti taimenimetused = Nomina vernacula plantarum Estoniae. Eesti Teaduste Akadeemia Emakeele Seltsi Toimetised 20 (67). Tallinn: ETA Emakeele Selts.

Wallner, Rudolf 1929. Eesti rahvarohtude sõnastik: Käsiraamat apteekritele ja arstidele. Tallinn: Raamatu kokkuseadja väljaanne.

Weiss, Rudolf Fritz \& Fintelmann, Volker 2000. Herbal Medicine. 2., täiend tr. Stuttgart $\&$ New York: Thieme.

WHO Monographs on Selected Medicinal Plants 1. 1999. Geneva: World Health Organization. 


\title{
Summary
}

\section{About the Vitality of Estonian Ethnopharmaconosy on the Example of Camomile}

\author{
Ain Raal, Elmar Arak
}

Keywords: Estonian ethnopharmacognosy, folk medicine, pharmacy, medicinal plants, camomile

The ethnopharmacognosy is an acknowledged and modern trend when it comes to discovering new medicinal plants and broadening the field of use of the herbs that have been known for a long time. Throughout times, camomile has been the most widely used medicinal plant. It is also the most popular herb in the former Soviet Union and in Russia, and is also widely used in Germany, etc.

In Estonia, two types of camomile can be found. The German camomile with white ligulate ray-florets (Chamomilla recutita (L.) Rauschert, syn. Matricaria recutita L., syn. M. chamomilla L.) grows only here and there in nature and the drug is mainly obtained from cultivating the plant. Pineapple weed without ray-florets (Chamomilla suaveolens (Pursh) Rydb., syn. M. suaveolens (Pursh) Buchen, syn. M. discoidea DC., syn. M. matricarioides (Less.) Porter p.p.) is a widely spread weed in the nature.

The Pharmacopoeia of the Soviet Union, which was effective in Estonia for half a century, permitted the use of the inflorescence of pineapple weed as a substitute for the inflorescence of German camomile, but only for external use. According to the pharmacopoeia, the camomile inflorescence has an anti-inflammatory and spasmolytic effect. Different authors have different viewpoints as regards the internal use of the pineapple weed. It is also unclear whether pineapple weed could be used as a substitute for German camomile.

The present article analyses the vitality of Estonian ethnopharmacognosy with the example of camomile as our most popular medicinal plant. The available folk medicinal data has enabled us to propose the following hypotheses:

1 . The complex of biologically active substances is chemically and pharmacologically close in case of pineapple weed and German camomile.

2. The complex of biologically active substances of pineapple weed and German camomile is quantitatively similar in inflorescence, as well as in leaves and stalks. It is possible to use the drug instead of the inflorescence.

3. Pineapple weed can be used for internal purposes.

The article gives an overview of the effect of the main components of the essential oil of German camomile; the process of working out the solubilisate of German camomile, the analysis of its toxicity and clinical research; the toxicity test of pineapple weed; the antimicrobial effect of the essential oils, herbal teas and powders of both German camomile and pineapple weed; the spasmolytic effect of the herbal teas of both plants. The article takes a closer look at the comparison of the chemical composition of both German camomile and pineapple weed. The article shows that besides the inflorescence of pineapple weed, it is pragmatic to use the drug of pineapple weed (top at the length of $2 / 3$ ), which also is suitable to substitute the inflorescence 
of German camomile. The data from the pharmacognostic, phytochemical and pharmacological research introduced in this article has confirmed the experiences of our ancestors in every way. Corresponding research has been carried out by the authors in Estonia as well as in the former Soviet Union and other countries.

The authors believe that these results give us a reason and courage to proceed with ethnopharmacognosy while planning pharmaceutical research also on other medicinal plants. This would help to propose hypotheses for studying them and save time and resources needed for pharmacognostic research. In a philosophical sense, the ethnopharmacognosy and pharmacognosy are opposites that do not exclude each other. 